\title{
GABA- and Glutamate-Activated Channels in Green Fluorescent Protein-Tagged Gonadotropin-Releasing Hormone Neurons in Transgenic Mice
}

\author{
Daniel J. Spergel, Ulrich Krüth, Daniel F. Hanley, Rolf Sprengel, and Peter H. Seeburg \\ Department of Molecular Neuroscience, Max-Planck-Institute for Medical Research, 69120 Heidelberg, Germany
}

Mice were generated expressing green fluorescent protein (GFP) under the control of the gonadotropin-releasing hormone $(\mathrm{GnRH})$ promoter. Green fluorescence was observed in, and restricted to, GnRH-immunopositive neuronal somata in the olfactory bulb, ganglion terminale, septal nuclei, diagonal band of Broca (DBB), preoptic area (POA), and caudal hypothalamus, as well as $\mathrm{GnRH}$ neuronal dendrites and axons, including axon terminals in the median eminence and organum vasculosum of the lamina terminalis (OVLT). Whole-cell recordings from GFPexpressing $\mathrm{GnRH}$ neurons in the OVLT-POA-DBB region revealed a firing pattern among GFP-expressing $\mathrm{GnRH}$ neurons distinct from that of nonfluorescent neurons. Nucleated patches of GFP-expressing $\mathrm{GnRH}$ neurons exhibited pronounced responses to fast application of GABA and smaller responses to L-glutamate and AMPA. One-fifth of the nucleated patches responded to NMDA. The GABA-A, AMPA, and NMDA receptor channels on $\mathrm{GnRH}$ neurons mediating these responses may play a role in the modulation of $\mathrm{GnRH}$ secretory oscillations.

Key words: diagonal band of Broca; GABA; GFP; glutamate; $\mathrm{GnRH}$; hypothalamus; median eminence; organum vasculosum of the lamina terminalis; preoptic area; transgenic mice
Gonadotropin-releasing hormone $(\mathrm{GnRH})$ neurons are a small and scattered group of primarily hypothalamic neurosecretory cells that synthesize the decapeptide GnRH and play a critical role in mammalian sexual development and reproduction (for review, see Lopez et al., 1998). During late embryogenesis, GnRH neurons migrate from the olfactory placode to the hypothalamus (Schwanzel-Fukuda and Pfaff, 1989; Wray et al., 1989). From embryonic day 17 onward in rodents, the cell bodies of GnRH neurons form a loose network extending from the olfactory bulb to the septal nuclei to the diagonal band of Broca (DBB), preoptic area (POA), and caudal hypothalamus (Wray and Hoffman, 1986; Wu et al., 1997). Beginning with puberty, GnRH neurons projecting to the median eminence release GnRH at a rate of $\sim 1-2$ pulses/hr into the hypothalamohypophyseal portal circulation (Levine and Ramirez, 1982). GnRH subsequently binds to receptors on pituitary gonadotrophs and stimulates the release of luteinizing hormone and follicular-

Received Oct. 19, 1998; revised Dec. 28, 1998; accepted Dec. 28, 1998.

D.J.S. was supported by an Alexander von Humboldt Foundation Research Fellowship, Deutsche Forschungsgemeinschaft Grant SFB317 and National Institutes of Health Individual National Research Service Award F32-NS10085. D.F.H. was supported by an Alexander von Humboldt Foundation Research Award. This work was funded in part by grants from the Volkswagen Foundation and the German Chemical Society to P.H.S. We are grateful to Dr. N. Muzyczka (University of Florida, Gainsville, FL) for the GFP-containing plasmid pTR-UF2 and to Dr. R. Benoit (Montréal General Hospital, Montréal, Quebec, Canada) for the GnRH antiserum LR1. We thank I. Angermann, Y. Cully, S. Grünewald, M. Hauswirth, A. Herold, R. Pfeffer, and F. Zimmermann for excellent technical assistance, and Dr. F. J. P. Ebling (University of Cambridge, Cambridge, UK), L. Johnson, Dr. K. Kaiser, Dr. G. Köhr, and A. Rozov for helpful discussions.

Correspondence should be addressed to Dr. Daniel J. Spergel, Department of Molecular Neuroscience, Max-Planck-Institute for Medical Research, Jahnstrasse 29, 69120 Heidelberg, Germany.

Drs. Spergel and Krüth contributed equally to this work.

Dr. Hanley's present address: Department of Neurology, Johns Hopkins University School of Medicine, Meyer 8-140, 600 North Wolfe Street, Baltimore, MD 21287-7840.

Copyright (ㄷ) 1999 Society for Neuroscience $\quad 0270-6474 / 99 / 192037-14 \$ 05.00 / 0$ stimulating hormone into the general circulation (Lopez et al., 1998).

Despite the importance of GnRH neurons, their physiology and differentiation, as well as the basic mechanisms underlying their pulsatile release of $\mathrm{GnRH}$, remain to be elucidated. Slow progress in this field primarily reflects the scarcity of $\mathrm{GnRH}$ neurons ( $~ 800$ per animal; Wray and Hoffman, 1986; Wu et al., 1997) and the lack of morphological criteria by which they can be identified in live brain slice preparations. Previous attempts to tag GnRH neurons by using the well characterized GnRH promoter (Mason et al., 1986a,b; Whyte et al., 1995) either generated immortalized GnRH cell lines expressing simian virus 40 (SV40) T-antigen (Mellon et al., 1990) or used luciferase as a reporter (Wolfe et al., 1996), which cannot be easily monitored in slice preparations. We have now used this promoter to express in transgenic mice a gene encoding a red-shifted variant of jellyfish green fluorescent protein (GFP) (Chalfie et al., 1994; Heim and Tsien, 1996). In these mice, detectable GFP expression was confined to GnRH neurons. Using combined fluorescence and infrared differential interference contrast (IR-DIC) video microscopy in a brain slice preparation of GnRH-GFP mice, we obtained physiological recordings of action potentials and GABA- and L-glutamate-evoked currents from identified, postembryonic GnRH neurons.

\section{MATERIALS AND METHODS}

Generation of GnRH-GFP transgenic mice. A $3.47 \mathrm{~kb}$ GnRH promoter fragment, along with 23 bp of exon 1 of the mouse GnRH gene (Mason et al., 1986a), was inserted together with the humanized GFP expression unit of pTR-UF2 (Zolotukhin et al., 1996), which contained an SV40 splice donor-splice acceptor intron and polyadenylation signal (Fig. $1 A$ ), into pLitmus29 (New England Biolabs, Beverly, MA) to create plasmid pmGnGFP. The 4644 bp GnRH-GFP minigene was released from vector sequences, by $A v r \mathrm{II} / N s i \mathrm{I}$ digestion, followed by sucrose gradient purification, and injected into C57B16/DBA mice-derived pronuclei according to the procedure of Suchanek et al. (1997). Founders and subsequent generations of GnRH-GFP mice were selected by PCR analysis of mouse 

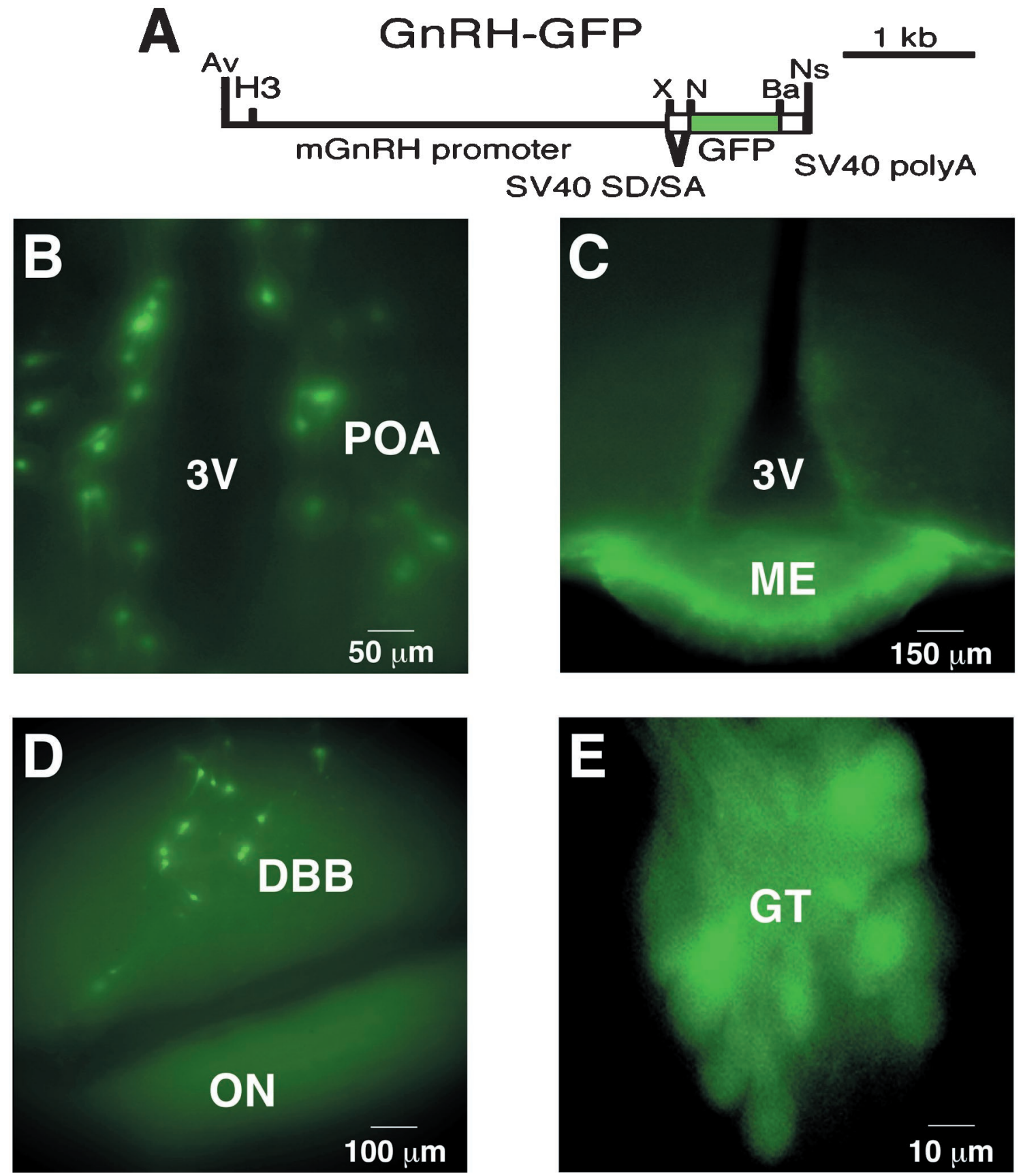

Figure 1. GFP reporter gene and GFP-expressing neurons in live $300 \mu \mathrm{m}$ brain slices from GnRH-GFP transgenic mice. $A$, GFP reporter gene used to generate GnRH-GFP transgenic mice. Restriction sites for cloning (Av, AvrII; H3, HindIII; X, XhoI; N, NotI; Ba, BamHI; Ns, NsiI) and regulatory elements of the minigene [SV40 SD/SA, SV40 splice donor/splice acceptor intron (Zolotukhin et al., 1996); SV40 polyA, SV40 polyadenylation signal] are indicated. $B$, GFP-expressing neurons in the POA of a coronal slice from a postnatal day 25 (P25) male GnRH-GFP mouse. The dark band in the middle of this image and in $C$ is the third ventricle $(3 V)$. $C$, GFP-expressing axon terminals in the median eminence from the same mouse as in $B$. $D$, GFP-expressing neurons in the DBB of a sagittal slice from a P21 male GnRH-GFP mouse. E, GFP-expressing neurons in the ganglion terminale (GT) of a sagittal slice from a P45 male GnRH-GFP mouse. This mouse and the one from which the images in Figure $6 \mathrm{~A}$ were obtained came from a different GnRH-GFP founder line than the mice from which the other images presented here were obtained.

tail DNA (Brusa et al., 1995) with primer GnRH 51 (GAAGTACTCAACCTACCAACGGAAG) and antisense primer hGFP1 (GCCATCCAGTTCCACGAGAATTGG), which amplified a 278 bp DNA fragment in mice transgenic for the GnRH-GFP minigene.

Tissue preparation. Male and female GnRH-GFP-positive mice, 1-week- to 6-month-old, were anesthetized with halothane (Hoechst, Frankfurt, Germany) and then decapitated. Brains were dissected in ice-cold gassed $\left(95 \% \mathrm{O}_{2}-5 \% \mathrm{CO}_{2}\right)$ Ringer's solution (Biometra, Göttingen, Germany) containing $125 \mathrm{~mm} \mathrm{NaCl}, 25 \mathrm{~mm} \mathrm{NaHCO}, 1.25 \mathrm{~mm}$ $\mathrm{NaH}_{2} \mathrm{PO}_{4}, 2.5 \mathrm{~mm} \mathrm{KCl}, 2 \mathrm{~mm} \mathrm{CaCl}{ }_{2}, 1 \mathrm{mM} \mathrm{MgCl}_{2}$, and $25 \mathrm{~mm}$ glucose,
$316 \mathrm{mOsm}, \mathrm{pH}$. 7.4, and cut coronally or sagittally into $300 \mu \mathrm{m}$ slices with a vibratome (Vibroslice Tissue Slicer $752 \mathrm{M}$; Campden Instruments, Loughborough, UK), similar to that described by Sakmann and Stuart (1995). Slices were transferred using the back end of a Pasteur pipette to an incubation chamber with Ringer's solution (equilibrated with $95 \%$ $\mathrm{O}_{2}-5 \% \mathrm{CO}_{2}$ ) for $30 \mathrm{~min}$ at $33^{\circ} \mathrm{C}$ and then were stored at room temperature $\left(20-22^{\circ} \mathrm{C}\right)$ in the same chamber until staining or imaging and recording.

GnRH immunostaining. Slices were immunostained for GnRH using a modification of a procedure described by Ebling et al. (1995). Briefly, 
each slice was transferred to an individual well in a 24-well plate, fixed for $1 \mathrm{hr}$ in $4 \%$ paraformaldehyde (PFA)-PBS, washed twice with PBS, and incubated for $1 \mathrm{hr}$ in $2 \%(\mathrm{v} / \mathrm{v})$ normal goat serum (Vector Laboratories, Burlingame, CA) in PBS supplemented with $1 \%(\mathrm{w} / \mathrm{v})$ bovine serum albumin (BSA) and $0.3 \%(\mathrm{v} / \mathrm{v})$ Triton X-100 (referred to here as day 1 buffer). Slices were then placed overnight in day 1 buffer containing the polyclonal antiserum LR1, which recognizes amino acids 6-10 of GnRH in pro-GnRH and GnRH (Silverman et al., 1990), at 1:10,000. The following day, slices were washed twice with PBS supplemented with $0.3 \%$ BSA and $0.1 \%$ Triton X-100 (referred to here as day 2 buffer), incubated for $1 \mathrm{hr}$ in 7-amino-4-methylcoumarin-3-acetic acidconjugated goat anti-rabbit IgG (Jackson ImmunoResearch, West Grove, PA) at 1:100 in day 2 buffer, washed twice with day 2 buffer, three times in PBS followed by $\mathrm{H}_{2} \mathrm{O}$, and then mounted on poly-L-lysine-coated glass slides using an aqueous medium (Mowiol 4.88; Polysciences, Warrington, PA). Immunostained slices were viewed using an upright fluorescence microscope (Axioskop; Zeiss, Göttingen, Germany) outfitted with Zeiss filter set 02, consisting of excitation filter G365, dichroic mirror FT395, and emission filter LP420.

Fluorescence and infrared imaging. For imaging and recording, slices were transferred to a $3 \mathrm{ml}$ Plexiglas recording chamber, fixed in place with a grid, and superfused at a rate of $20 \mathrm{ml} / \mathrm{hr}$ with Ringer's solution at room temperature. Slices were viewed with a fluorescence microscope (Axioskop) equipped with Dodt-Gradient-Contrast (Luigs \& Neumann, Ratingen, Germany), first in bright field with a $5 \times$ objective (PlanNeofluar; Zeiss) and then with a $20 \times$ objective (LD Achroplan; Zeiss).

To visualize GFP, the white light from the bright-field lamp was blocked by a 780/50 $\mathrm{nm}$ bandpass filter (Luigs \& Neumann), which was also used for infrared imaging (see below), and a fluorescent lamp (HBO 100W; Osram, Berlin, Germany) was switched on. The intensity of the fluorescent lamp was regulated by an AttoArc power supply (Zeiss). GFP filter set 41017, consisting of excitation filter HQ470/40, dichroic mirror Q495LP, and emission filter HQ525/50 (Chroma Technology, Brattleboro, VT), was used. After observing a fluorescent neuron with the $20 \times$ objective, a $60 \times$ water-immersion objective (LUMPlanFl; Olympus, Hamburg, Germany) was used for further imaging and to view cells for patch-clamp recording. Fluorescence images (16 bit) were acquired with a back-illuminated, cooled, slow-scan charge-coupled device (CCD) camera (TEA/CCD-800-PB/VISAR/1; Princeton Instruments, Trenton, NJ) controlled from an IBM-compatible personal computer (PC) with MetaMorph 3.0 software (Universal Imaging, West Chester, PA), displayed on a color monitor, converted to 8 bit with NIH Image 1.61, and processed further with Adobe Photoshop 4.0 software (Adobe Systems, San Jose, CA) on a Power Macintosh computer.

IR-DIC imaging (Dodt and Ziegelgänsberger, 1990; Sakmann and Stuart, 1995) was performed subsequent to fluorescence observation or imaging to visualize neurons for electrophysiological experiments. After viewing a fluorescent neuron, the magnification was increased by $1.6 \times$ using an intermediate phototube (Zeiss) and the light directed to an infrared camera (C2400-07; Hamamatsu Photonics, Herrsching, Germany) mounted on the same binocular phototube (Zeiss) as the CCD camera. The IR-DIC image was displayed on a black and white monitor (Panasonic WV-BM1400/G), transferred to the hard disk of a PC using an image frame grabber controlled by MetaMorph, stored as an 8-bit image, and processed further with Adobe Photoshop. A neuron viewed with infrared optics was considered to be the same as that viewed with fluorescence optics when the infrared image and the fluorescent image of the neuron had the same position and orientation with the two imaging systems or, alternatively, through the eyepiece of the microscope (fluorescent image) and with the infrared imaging system (infrared image).

Whole-cell patch clamp recording. Whole-cell, as well as nucleated patch (see below), recordings were made from neurons in the organum vasculosum of the lamina terminalis (OVLT)-POA-DBB region in coronal and sagittal slices. Whole-cell recordings were performed as described previously (Sakmann and Stuart, 1995). Recording pipettes made from thick-walled borosilicate glass (outer diameter of $2 \mathrm{~mm}$, wall thickness of $0.5 \mathrm{~mm}$; Hilgenberg, Malsfeld, Germany) were pulled using a Flaming/Brown micropipette puller (P-97; Sutter Instrument Co., Novato, CA) filled with an intracellular solution, consisting of $140 \mathrm{~mm} \mathrm{KCl,}$ $2 \mathrm{mM}$ Mg-ATP, $10 \mathrm{~mm}$ EGTA, and $10 \mathrm{~mm}$ HEPES, pH adjusted to 7.30 with KOH, 286 mOsm. Pipettes used for whole-cell recording had resistances of 2.5-3.5 $\mathrm{M} \Omega$ when filled with this solution. Pipettes were connected via an $\mathrm{Ag}-\mathrm{AgCl}$ wire to the headstage of an EPC-9 patch clamp amplifier (HEKA, Lambrecht, Germany). The reference electrode was an $\mathrm{Ag}-\mathrm{AgCl}$ pellet (IVM, Healdsburg, CA) immersed in bath solution. The EPC-9 amplifier and Pulse 8.09 software (HEKA) were used to acquire ( 5 or $100 \mathrm{kHz}$ in current clamp, for long duration or high temporal resolution, respectively, and $10 \mathrm{kHz}$ in voltage clamp), filter (1.67 or $33.3 \mathrm{kHz}$ in current clamp and $3.33 \mathrm{kHz}$ in voltage clamp; Bessel), and analyze patch-clamp data, which was stored on a Power Macintosh computer. The patch-clamp amplifier was also used to compensate pipette capacitance, cell capacitance, and series resistance, and to correct for leak and capacitive currents. Traces were processed for presentation using Igor 3.03 (Wavemetrics, Lake Oswego, OR) and Canvas 5.0 (Deneba, Miami, FL) software.

Biocytin labeling. Biocytin labeling, followed by GnRH immunostaining, was performed to confirm the identity of cells from which recordings were obtained. Biocytin ( $8 \mathrm{~mm}$ final concentration) was added to the pipette solution used for whole-cell recording, after which the solution was filtered and sonicated. After establishing the whole-cell configuration, biocytin diffused into the cell for the duration of the recording $(30-45 \mathrm{~min})$. The pipette was then slowly withdrawn from the cell so that an outside-out patch was formed and the cell remained intact. The slice was put into a second slice incubation chamber for $1 \mathrm{hr}$ to allow complete diffusion of biocytin throughout the cell. Subsequently, the slice was placed in 4\% PFA-PBS, immunostained for GnRH as described above, incubated in $0.5 \%(\mathrm{v} / \mathrm{v})$ Texas Red-conjugated avidin (Jackson ImmunoResearch) in PBS, mounted as described above, and then viewed under the fluorescence microscope (Axioskop) using filter set XF33 (Omega Optical, Brattleboro, VT), consisting of excitation filter 535DF35, dichroic mirror 570DRLPO2, and emission filter 605DF50.

Nucleated patch recording. Nucleated outside-out patches were formed by establishing the whole-cell recording configuration, applying suction through the patch pipette, and then slowly withdrawing the pipette from the cell as described by Sather et al. (1992). In our initial experiments, the intracellular solution was the same as that used for whole-cell recording, except that $\mathrm{KCl}$ was replaced by $\mathrm{CsCl}$. In subsequent experiments, we used the same intracellular solution as for whole-cell recording because we found it easier to obtain nucleated patches with this solution. However, at depolarized holding potentials, this potassiumbased intracellular solution resulted in outward potassium currents before and during the agonist-evoked outward current. Pipettes used for nucleated patch recording had resistances of 5-8 $\mathrm{M} \Omega$ when filled with this solution. Data from nucleated patches were acquired at $10 \mathrm{kHz}$ and filtered at $3.33 \mathrm{kHz}$ (Bessel).

Fast application of agonists and antagonists. Agonists and antagonists were applied to nucleated patches via a double-barrelled pipette made from theta glass tubing (outer diameter of $2 \mathrm{~mm}$, inner diameter of 1.4 $\mathrm{mm}$, septum thickness of $0.22 \mathrm{~mm}$; Hilgenberg), pulled using an $\mathrm{L} / \mathrm{M}$ 3P-A pipette puller with insert 12, 11, and 5 (List Electronic, Darmstadt, Germany), and rapidly moved from side to side by a piezo translator controlled by a high-voltage amplifier (P-275.10; Physik Instrumente, Waldbronn, Germany) as described by Jonas (1995). One barrel of the application pipette was perfused with nominally $\mathrm{Mg}^{2+}$-free control solution, consisting of $152 \mathrm{~mm} \mathrm{NaCl}, 5.8 \mathrm{~mm} \mathrm{KCl}, 1.9 \mathrm{mM} \mathrm{CaCl}_{2}, 5.4 \mathrm{~mm}$ HEPES, and $10 \mu \mathrm{M}$ glycine, $\mathrm{pH}$ adjusted to 7.25 with $\mathrm{NaOH}, 290 \mathrm{mOsm}$, with or without antagonists, and the other barrel with control solution containing agonists with or without antagonists. Perfusion was performed using a peristaltic pump (IPC-N8; Ismatec, Zurich, Switzerland). Complete solution exchange was achieved in $5 \mathrm{msec}$, as determined by the open-tip response for the application pipette (Jonas, 1995).

Statistics. Data are expressed as mean \pm SEM except as indicated. Statistical comparisons were performed using the Kruskal-Wallis test followed by the Mann-Whitney $U$ test (Winer, 1971). A difference between groups was considered to be significant if the probability value ( $p$ ) obtained from the Mann-Whitney $U$ test was $<0.05$.

Reagents. The glutamate receptor agonist AMPA, the AMPA-kainate receptor antagonist 6-nitro-7-sulfamoylbenzo[f]quinoxaline-2,3-dione (NBQX), and the NMDA receptor antagonist D(-)-2-amino-5phosphonopentanoic acid (D-AP-5) were purchased from Tocris (Bristol, UK). Unless indicated otherwise, all other reagents were obtained from Sigma-Aldrich (Deisenhofen, Germany).

\section{RESULTS}

\section{GFP-expressing GnRH neurons in GnRH-GFP mice}

Three independent GnRH-GFP founder lines were obtained by pronucleus injection of the GnRH-GFP reporter gene. Analysis of live coronal and sagittal brain slices from all three lines revealed a small number, 1-150 per $300 \mu \mathrm{m}$-thick slice, of green 

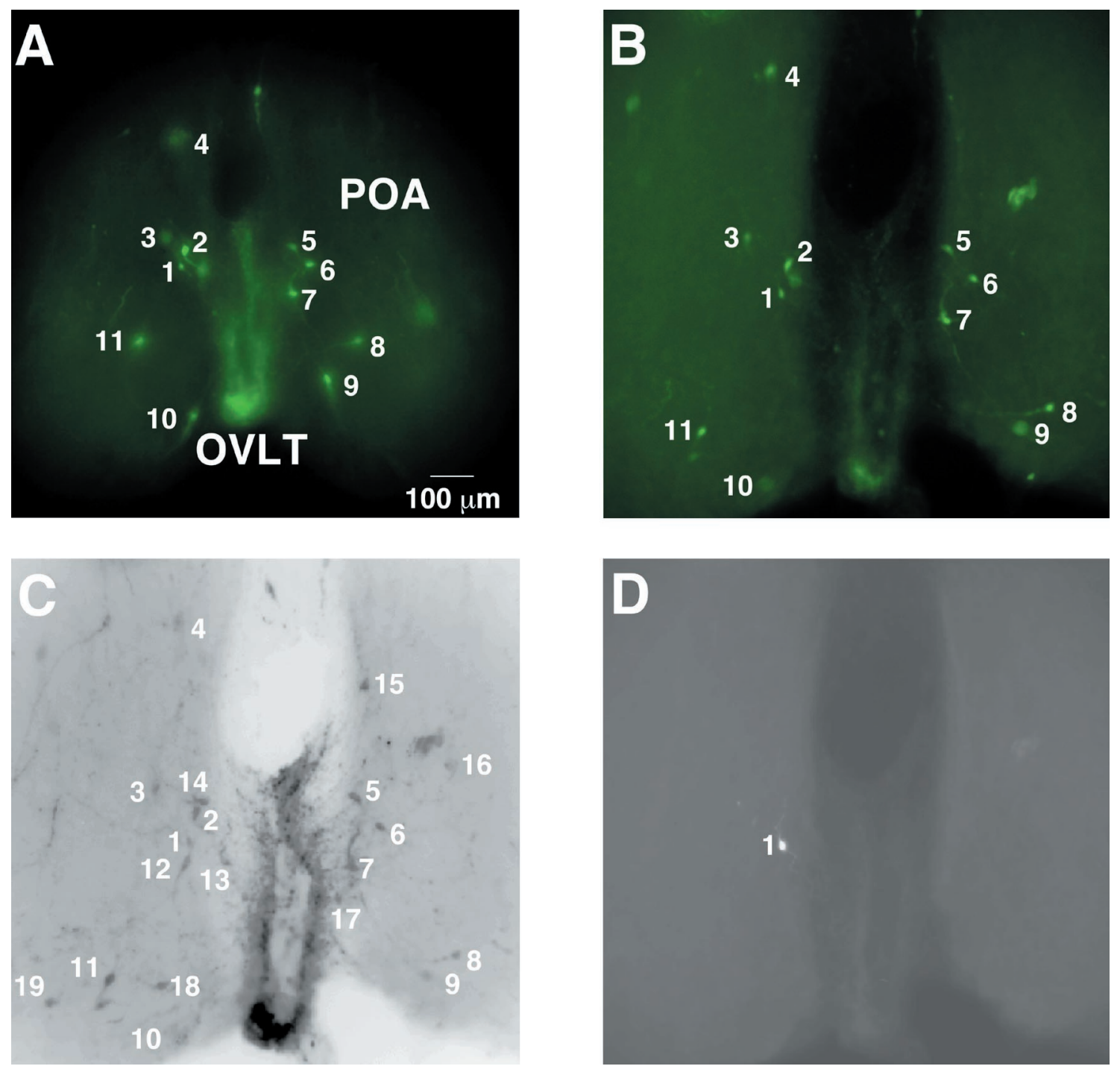

Figure 2. Comparison of GFP and GnRH expression in GnRH-GFP transgenic mice. $A$, GFP-expressing neurons, numbered 1-11, near the DBB-POA border at the level of the OVLT from the same mouse as in Figure $1 A$ but $300 \mu \mathrm{m}$ more rostral. The optic chiasm is missing because it detached from the rest of the tissue during slicing. $B$, Same slice as in $A$ after fixation, which produced additional fluorescence, and after mounting, which flattened the tissue and thereby changed the relative positions of the neurons. Scales in $B-D$ are the same as in $A$. $C$, Same slice as in $B$ after immunostaining for GnRH. GnRH-immunopositive neurons are numbered 1-19. The gray levels in this panel and in Figure $3 D$ have been inverted to aid the reader in visualizing the GnRH immunostained neurons, which appear as dark spots. Note that all fluorescent neurons in $B$ are GnRH-immunopositive in $C$ and that the number of GnRH-immunopositive neurons is larger than the number of fluorescent neurons. $D$, Same slice as in $A$ after biocytin labeling of neuron 1 .

fluorescent cells (a number that remained constant during the course of an experiment, which typically lasted 6-12 hr), whereas wild-type litter mates showed no green fluorescent cells. Green fluorescent cells were confined to areas in which $\mathrm{GnRH}$ neurons are known to be distributed (Fig. $1 B-E$ ). These areas include the olfactory bulb, ganglion terminale, medial and lateral septal nuclei, DBB and POA, which contained the largest number of green fluorescent cells, and the following caudal hypothalamic regions: retrochiasmatic area, supraoptic nucleus retrochiasmatic, lateral hypothalamic area, and arcuate nucleus. GFP fluorescence was also detected in axons and dendrites in these areas, as well as in axon terminals in the OVLT and median eminence. Green fluorescent cells were bright and could be seen easily through the microscope; however, a CCD camera-based imaging system (see Materials and Methods) was also used to record images of green fluorescent cells for subsequent analysis.

To test whether all green fluorescent cells contained GnRH and vice versa, GFP fluorescence was recorded from slices before and after fixation. Subsequently, the slices were immunostained for $\mathrm{GnRH}$, and the images were compared with those of green fluorescence (Fig. 2). All green fluorescent neurons $(n=556)$ in the 14 slices from the four GnRH-GFP mice that were analyzed contained GnRH. We observed green fluorescence in only $65 \%$ of all GnRH neurons, perhaps because the fluorescence in the remaining GnRH neurons was below detection.

\section{Action potentials, passive electrical properties, and voltage-gated currents of GnRH neurons}

GFP-expressing GnRH neurons in the OVLT-POA-DBB region, identified by fluorescence microscopy, were subsequently visualized for whole-cell patch-clamp recording by IR-DIC imaging. Cells on the IR video monitor screen, whose coordinates and orientation matched those of fluorescent cells seen in the microscope, were recorded from. To further confirm that the 

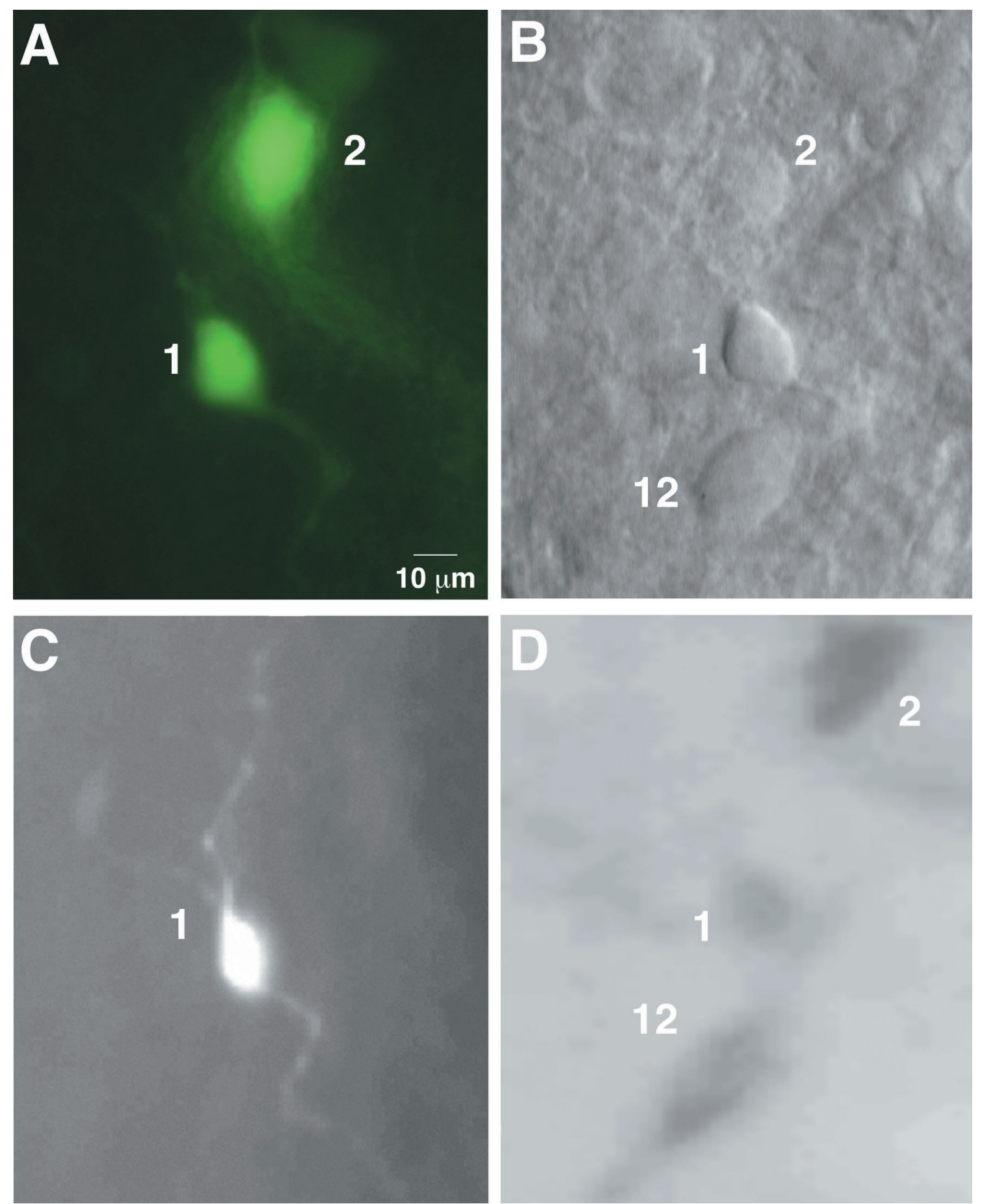

Figure 3. Post hoc identification of GFP-expressing neurons used in physiological recordings. $A$, High-magnification fluorescence image of GFPexpressing neurons 1 and 2 in Figure $2 A$. B, IR-DIC image of neurons 1, 2, and 12 in Figure $2 C$. Scales in $B-D$ are the same as in $A$. $C$, High-magnification fluorescence image of neuron 1 after biocytin labeling. D, High-magnification fluorescence image of neurons 1, 2, and 12 after GnRH immunostaining. Neurons 1 and 2 fluoresce and contain GnRH, whereas neuron 12 contains GnRH but does not fluoresce.

fluorescent cells recorded from were GnRH neurons, the cells were filled with biocytin, fixed, and then immunostained for GnRH (Figs. 2, 3). As expected, all biocytin-filled fluorescent neurons $(n=8)$ contained GnRH. In current-clamp mode, GFPexpressing GnRH neurons were quiescent or displayed spontaneous low-frequency (up to $4 \mathrm{~Hz}$ ) action potentials. Action potentials of a similar distinctive shape, marked by a long afterhyperpolarization (Fig. 4), were observed in all GnRH neu- rons analyzed $(n=26)$ in the three independent lines of GnRHGFP mice, regardless of the age or sex of the mouse. In contrast, six other shapes of action potential differing in the degree and time course of afterhyperpolarization (Fig. 4) were observed among neighboring nonfluorescent neurons $(n=26)$.

To illustrate the differences in action potential shape, a comparison between GnRH neurons (Fig. 4B) and one type of neighboring nonfluorescent neuron (Fig. 4C, top left trace) shows 

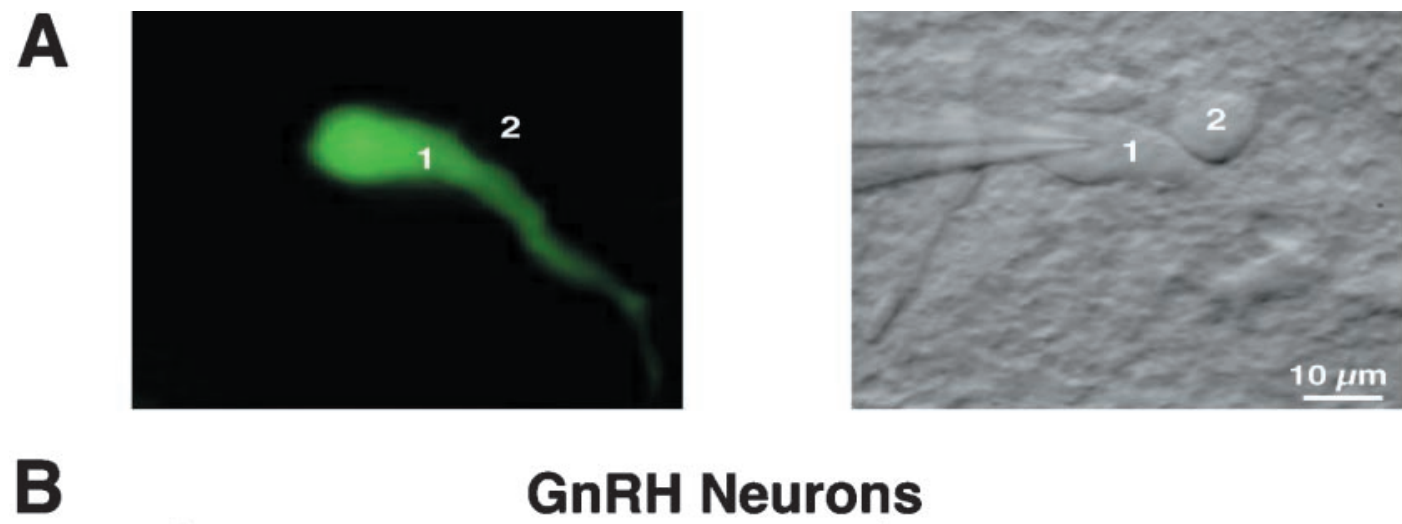

GnRH Neurons
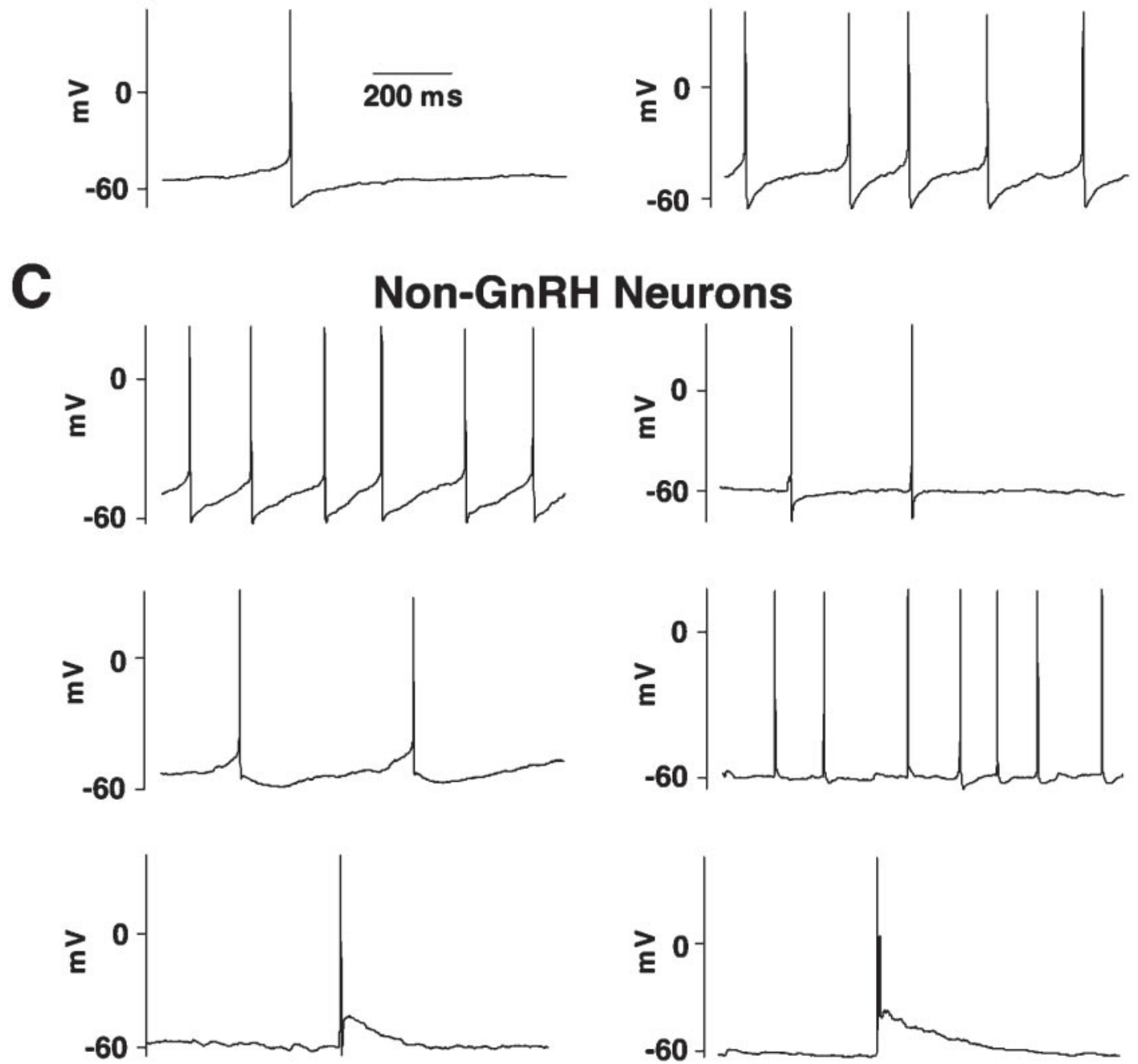

Figure 4. Comparison of spontaneous action potentials in GFP-expressing GnRH neurons with those in neighboring nonfluorescent, non-GnRH hypothalamic neurons. A, Fluorescence (left) and IR-DIC (right) images of a GFP-expressing GnRH neuron (1) and a neighboring nonfluorescent neuron (2) during a whole-cell patch-clamp recording of action potentials in the GnRH neuron. The neurons were in the DBB of a sagittal brain slice from a P21 female GnRH-GFP mouse. B, Spontaneous action potentials with long afterhyperpolarizations in GFP-expressing GnRH neurons in the POA of a P44 male GnRH-GFP mouse (left) and in the DBB of a P19 male GnRH-GFP mouse (right). Calibrations in this panel and in $C$ are the same. $C$, Six shapes of spontaneous action potential in nonfluorescent neurons neighboring GFP-expressing GnRH neurons. Top left, Action potentials in a nonfluorescent neuron neighboring the GnRH neuron whose action potential is shown in the left trace of $B$. These action potentials are characterized by a brief afterhyperpolarization, followed by a slow return to the resting potential. Action potentials of this shape were observed in 15 of 26 , or $58 \%$ of, nonfluorescent neurons. Each of the other action potential shapes shown below was seen in $\leq 15 \%$ of nonfluorescent neurons. Top right, Action potentials in a nonfluorescent neuron neighboring the GnRH neuron whose action potentials are shown in the right trace of $B$. In this case, the brief afterhyperpolarization was followed by a fast return to the resting membrane potential. Middle left, Action potentials with a biphasic afterhyperpolarization in a nonfluorescent neuron in the DBB of a 6-month-old female GnRH-GFP mouse. Middle right, Action potentials with little or no afterhyperpolarization in a nonfluorescent neuron in the POA of a P23 female GnRH-GFP mouse. Bottom left, Action potential with an afterhyperpolarization, followed by an afterdepolarization, in a nonfluorescent neuron in the POA of a P42 male GnRH-GFP mouse. Bottom right, Large action potential, followed by a small action potential and afterdepolarization but no afterhyperpolarization, in a nonfluorescent neuron in the DBB of a P15 male GnRH-GFP mouse. 

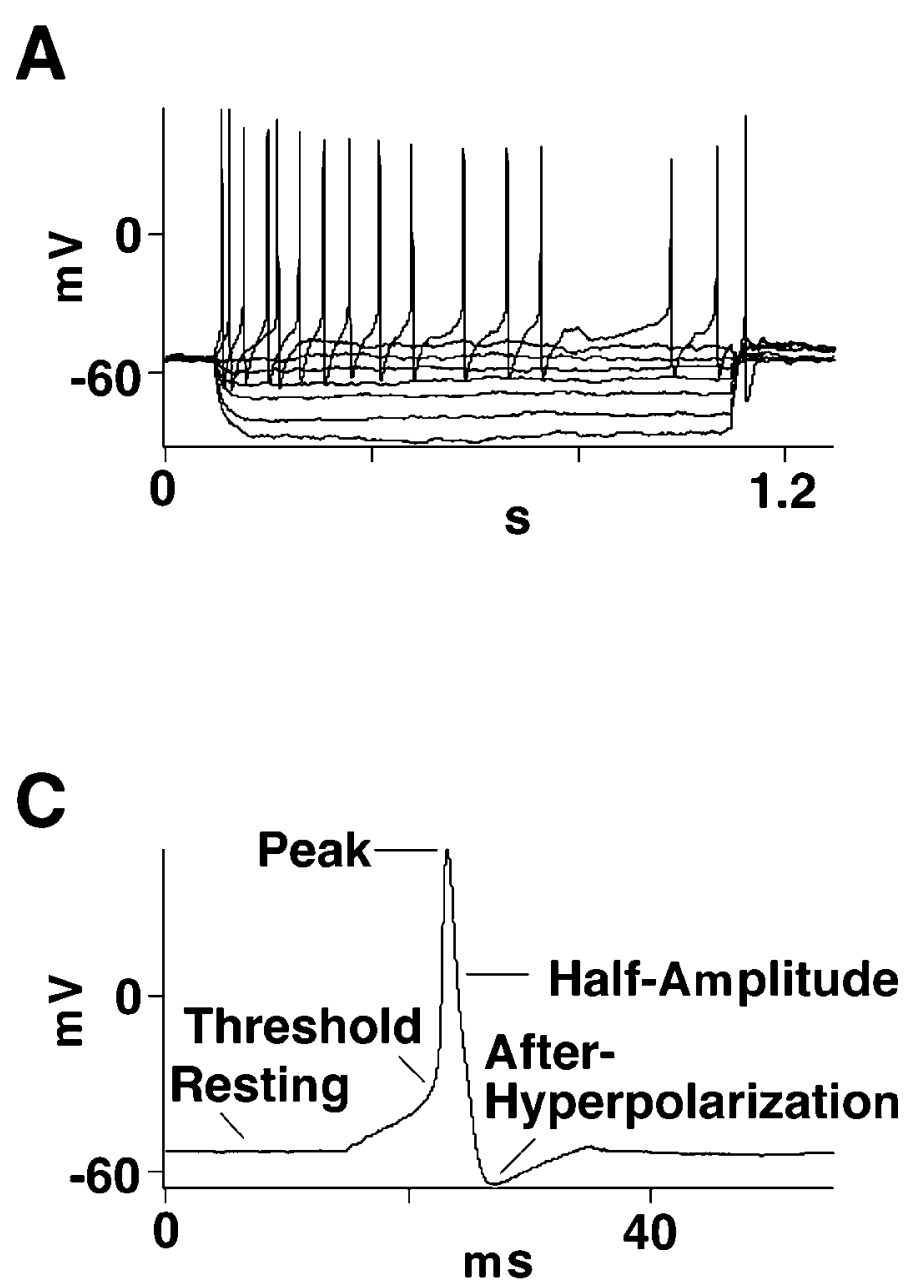

B

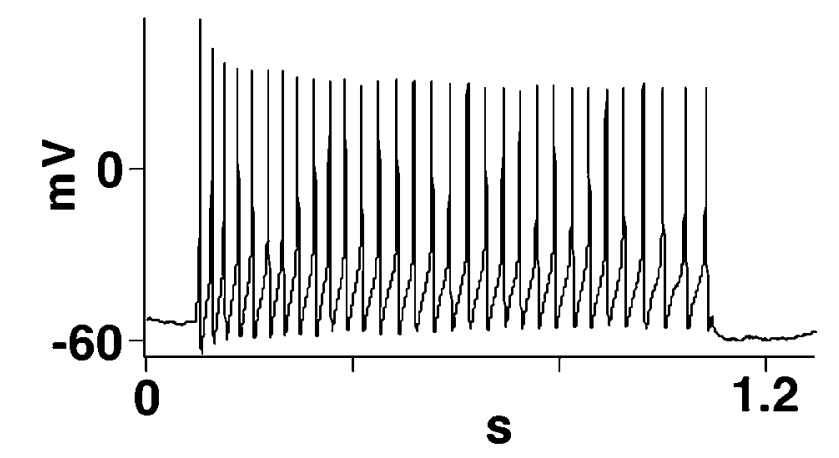

D

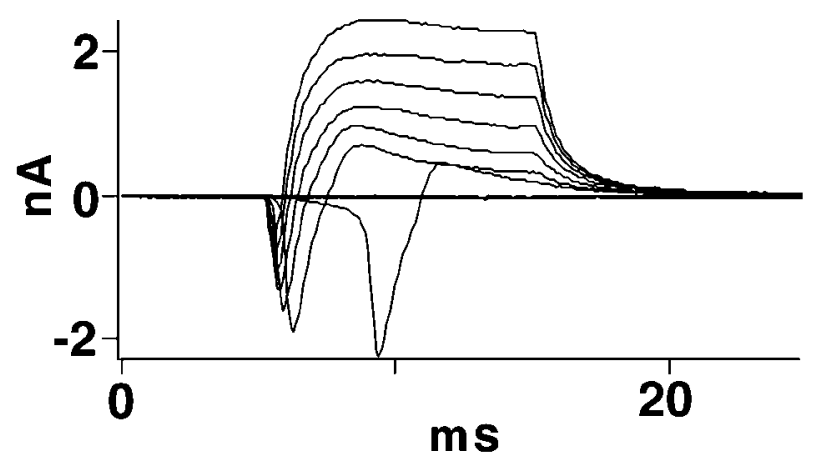

Figure 5. Responses of a GnRH neuron to hyperpolarizing and depolarizing current and voltage pulses. $A$, Passive and active responses to 1 sec current pulses of $-50,-40,-30,-20,-10,0,10$, and $20 \mathrm{pA}$ of a GFP-expressing GnRH neuron in the DBB of the 6-month-old female GnRH-GFP mouse from which the recording in Figure $4 H$ was obtained. $B$, Maximum firing evoked by a 1 sec depolarizing current pulse of $40 \mathrm{pA}$ in the GnRH neuron whose responses are shown in $A$. $C$, High-resolution recording of an action potential evoked by a $20 \mathrm{msec}$ depolarizing current pulse of $40 \mathrm{pA}$ in the same GnRH neuron. Resting, threshold, peak, half-amplitude, and afterhyperpolarization potentials are indicated. $D$, Voltage-gated currents in the same GnRH neuron in response to $10 \mathrm{msec}$ voltage pulses from a $V_{\mathrm{h}}$ of $-60 \mathrm{mV}$ to test potentials of $-140,-120,-100,-80,-60,-40,-20,0,20,40,60$, and $80 \mathrm{mV}$.

that in GnRH neurons the return to resting membrane potential during the action potential afterhyperpolarization is curved, whereas in the neighboring nonfluorescent neuron, it is linear. Neurons that displayed action potentials like those in Figure $4 C$ (top left trace) comprised $58 \%$ of the recorded nonfluorescent neurons. Because only a small percentage of the neurons in the OVLT-POA-DBB region are GnRH-immunopositive and only one-third of these are nonfluorescent, it made little sense to fill the $58 \%$ of nonfluorescent neurons with biocytin and stain for GnRH. The differences in shape between the action potential afterhyperpolarizations of GnRH neurons (Fig. 4B) and those of the other nonfluorescent neurons recorded from (Fig. 4C, all traces, except top left) were even more marked.

The passive electrical properties and evoked action potentials of GFP-expressing GnRH neurons were also recorded (Fig. $5 A-C$ ) and compared (Table 1 ) with those of non-GFP-expressing $\mathrm{GnRH}$ neurons, as well as with those of adult GnRH neurons identified post hoc (i.e., identified after recording) (Lagrange et al., 1995), with embryonic GnRH neurons in explant culture (Kusano et al., 1995), and with immortalized GnRH neurons in culture (Bosma, 1993; Hales et al., 1994). The maximal firing rate of the GFP-expressing GnRH neurons tended to be regular (i.e., the ratio of the maximal-to-minimal interspike interval was low), whereas that of non-GFP-expressing neurons was regular or irregular depending on the neuron. However, except for the differences in action potential shape noted above (and in Fig. 4), there were no significant differences $(p>0.05)$ between GFPexpressing GnRH neurons $(n=26)$ and non-GFP-expressing hypothalamic neurons $(n=26)$ in passive electrical properties or action potential characteristics. These included resting membrane potential, input resistance, membrane time constant, membrane capacitance, spontaneous and evoked spike frequencies, spike threshold, amplitude, duration at half-amplitude, rate of rise or fall, afterhyperpolarization potential, maximum and minimum interspike intervals, and the ratio of maximum-to-minimum interspike interval (Table 1). There were also no differences between the passive electrical properties of GFP-expressing GnRH neurons and those of adult GnRH neurons identified post hoc, for which the action potential characteristics have not been reported. Compared with embryonic (Kusano et al., 1995) and immortal- 
Table 1. Comparison of electrical properties and action potentials in GnRH and non-GnRH neurons

\begin{tabular}{|c|c|c|c|c|c|}
\hline & $\begin{array}{l}\text { GFP-expressing GnRH } \\
\text { neurons }(n=26)\end{array}$ & $\begin{array}{l}\text { Non-GFP-expressing } \\
\text { hypothalamic neurons } \\
(n=26)\end{array}$ & $\begin{array}{l}\text { Adult GnRH neurons }{ }^{a} \\
(n=8)\end{array}$ & $\begin{array}{l}\text { Embryonic } \\
\text { GnRH neurons }{ }^{b} \\
(n=13)\end{array}$ & $\begin{array}{l}\text { Immortalized } \\
\text { GnRH neurons } \\
(n=26)^{c}(n=4)^{d}\end{array}$ \\
\hline Resting potential (mV) & $-55.7 \pm 3.65$ & $-57.0 \pm 5.2$ & $-55.0 \pm 8.5$ & $-50.8 \pm 3.6$ & $-58 \pm 6^{d}$ \\
\hline Input resistance $(\mathrm{G} \Omega)$ & $1.2 \pm 0.5$ & $1.1 \pm 0.7$ & $0.5 \pm 0.2$ & $2.4 \pm 2.0 \#$ & NR \\
\hline Time constant (msec) & $30.4 \pm 16.5$ & $35.3 \pm 13.8$ & $23.0 \pm 14.1$ & $30.1 \pm 25.5 \#$ & NR \\
\hline $\begin{array}{l}\text { Membrane capacitance } \\
\quad(\mathrm{pF})\end{array}$ & $25.9 \pm 11.3$ & $41.6 \pm 20.8$ & 46.0 & $10 \#$ & $6.5 \pm 2.3^{c}$ \\
\hline $\begin{array}{l}\text { Spontaneous action } \\
\text { potentials }(\mathrm{Hz})\end{array}$ & $1.2 \pm 1.2$ & $2.2 \pm 3.0$ & $5.4 \pm 4.0$ & $(\operatorname{Max}=4)$ & $1^{d}$ \\
\hline $\begin{array}{l}\text { Evoked action poten- } \\
\text { tials }(\mathrm{Hz})\end{array}$ & $25.4 \pm 8.3(\mathrm{Max}=44)$ & $25.7 \pm 14.3$ & NR & $(\operatorname{Max}=16)$ & NR \\
\hline Threshold (mV) & $-32.2 \pm 3.9$ & $-39.9 \pm 5.7$ & NR & -37.5 & NR \\
\hline Amplitude (mV) & $79.5 \pm 9.8$ & $76.0 \pm 12.0$ & NR & 80 & NR \\
\hline $\begin{array}{l}\text { Duration at half-ampli- } \\
\text { tude (msec) }\end{array}$ & $1.2 \pm 0.3$ & $1.2 \pm 0.4$ & $2.5 \pm 0.7$ at $1 / 3$ amplitude & 2 & NR \\
\hline $\mathrm{dV} / \mathrm{dt}$ Rise $(\mathrm{mV} / \mathrm{msec})$ & $88.9 \pm 33.1$ & $105.0 \pm 39.9$ & NR & NR & NR \\
\hline dV/dt Fall (mV/msec) & $53.1 \pm 13.9$ & $63.1 \pm 23.6$ & NR & NR & NR \\
\hline $\begin{array}{l}\text { Afterhyperpolarization } \\
\text { potential }(\mathrm{mV})\end{array}$ & $-67.4 \pm 4.2$ & $-64.5 \pm 5.8$ & $-62.6 \pm 2.1$ & NR & NR \\
\hline $\begin{array}{l}\text { Maximum interspike } \\
\text { interval (msec) }\end{array}$ & $61.3 \pm 27.2$ & $82.1 \pm 62.7$ & NR & NR & NR \\
\hline $\begin{array}{l}\text { Minimum interspike } \\
\text { interval }(\mathrm{msec})\end{array}$ & $33.5 \pm 13.5$ & $37.7 \pm 39.3$ & NR & $\begin{array}{l}50 \\
1 \text { st to } 2 \text { nd }\end{array}$ & NR \\
\hline $\begin{array}{l}\text { Max/min interspike } \\
\text { interval ratio }\end{array}$ & $1.9 \pm 0.6$ & $2.5 \pm 1.5$ & NR & NR & NR \\
\hline
\end{tabular}

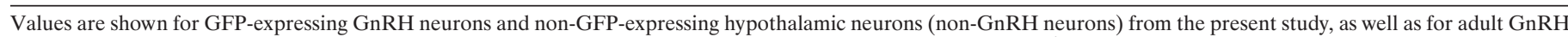

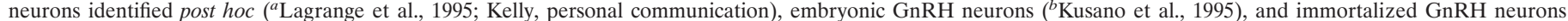

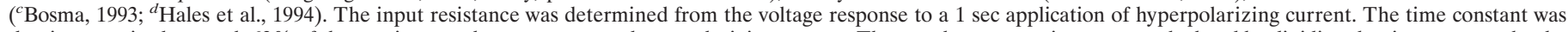

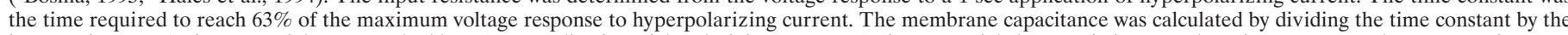

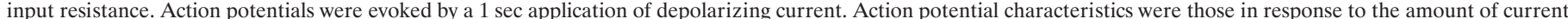

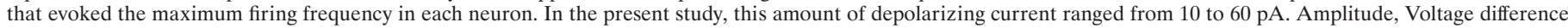

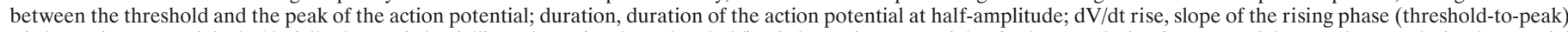

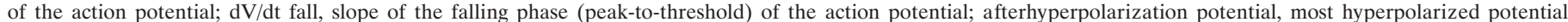

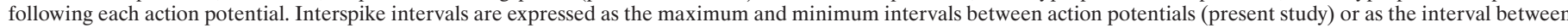
the first and second action potential (Kusano et al., 1995). Values are mean \pm SD, mean only, or maximum, whichever was reported. NR, Not reported; \#, $n=6$.

ized (Bosma, 1993; Hales et al., 1994) GnRH neurons, postembryonic GFP-expressing GnRH neurons in acute brain slices showed no differences, except for a higher membrane capacitance, perhaps reflecting their more extensive dendritic and axonal processes.

In voltage-clamp mode under imperfect space-clamp conditions, GFP-expressing GnRH neurons displayed little or no current in response to hyperpolarizing voltage pulses but exhibited inward sodium current, as well as transient and sustained outward potassium current in response to 10 (Fig. 5D) and $300 \mathrm{msec}$ (data not shown) depolarizing voltage steps $(n=39)$. These currents were similar to those in embryonic (Kusano et al., 1995) and immortalized (Bosma, 1993; Hales et al., 1994) GnRH neurons and may contribute to the shape of the action potentials in $\mathrm{GnRH}$ neurons.

\section{GABA- and glutamate-activated channels of GnRH neurons}

To determine whether GnRH neurons express functional receptors for the neurotransmitters GABA and L-glutamate, and which receptor subtypes, these transmitters were applied for $50 \mathrm{msec}$ periods at various holding potentials $\left(V_{\mathrm{h}}\right)$ to nucleated patches of GFP-expressing GnRH neurons of male and female mice ranging in age from 1 week to 6 months. All patches responded to GABA and glutamate, and neither the GABA nor the glutamate response depended on the age or sex of the mouse. The patches, which were fluorescent (Fig. $6 A$ ), responded to $1 \mathrm{~mm}$ GABA in a voltage-dependent manner with a fast current spike to a peak level, followed by a slow decline to a plateau within the $50 \mathrm{msec}$ of application, indicating slow receptor desensitization (Fig. 6B). At $V_{\mathrm{h}}$ of $-100 \mathrm{mV}$, for example, the peak current $\left(I_{\text {peak }}\right)$ was $-374 \pm 36 \mathrm{pA}$, and this was followed by a decline to a plateau within the $50 \mathrm{msec}$ of GABA application of $-179 \pm 21 \mathrm{pA}(n=$ $25)$. With similar chloride concentrations in the patch pipette and bath solutions, the current-voltage relationship for the peak response was nearly linear, with a reversal potential close to $0 \mathrm{mV}$ (Fig. 6C). The peak responses to GABA at $V_{\mathrm{h}}$ of $-100 \mathrm{mV}$ were inhibited by $89 \pm 2(n=5)$ (Fig. $6 D$, bottom traces) and $100 \%$ $(n=3)$ (Fig. $6 D$, top traces) in the presence of 50 and $100 \mu \mathrm{M}$ GABA-A antagonist (-)-bicuculline methobromide, respectively, indicating that the current was mediated entirely by GABA-A receptors.

The same nucleated patches of GFP-expressing GnRH neurons that exhibited large responses to $1 \mathrm{~mm}$ GABA displayed small responses to $1 \mathrm{mM} \mathrm{L-glutamate}\left(I_{\text {peak }}\right.$ of $\left.-28 \pm 3 \mathrm{pA} ; n=25\right)$ in the presence of $10 \mu \mathrm{M}$ glycine and the nominal absence of $\mathrm{Mg}^{2+}$ (Fig. 7A). Also, in contrast to the GABA responses, the peak current elicited by glutamate was followed by a decline to baseline 

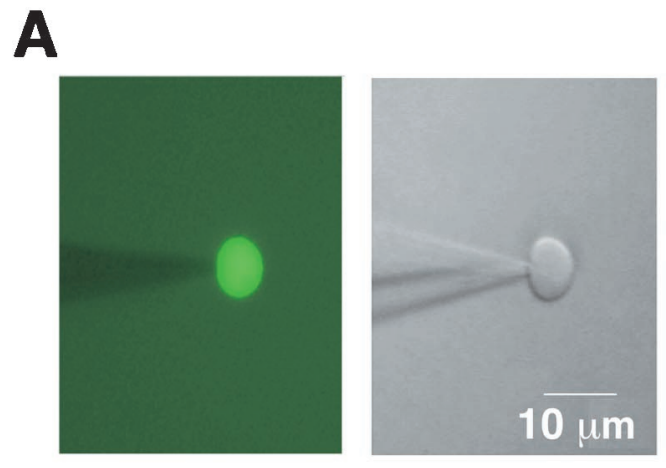

B

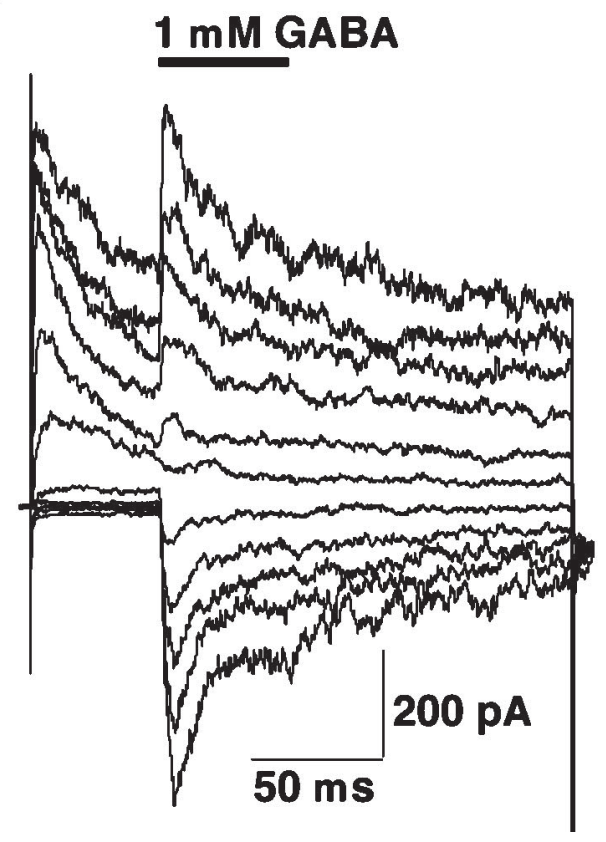

C

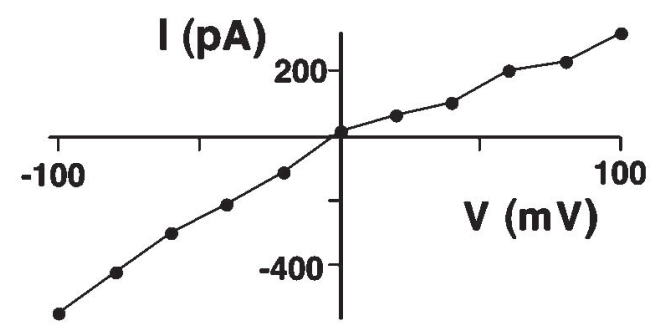

D

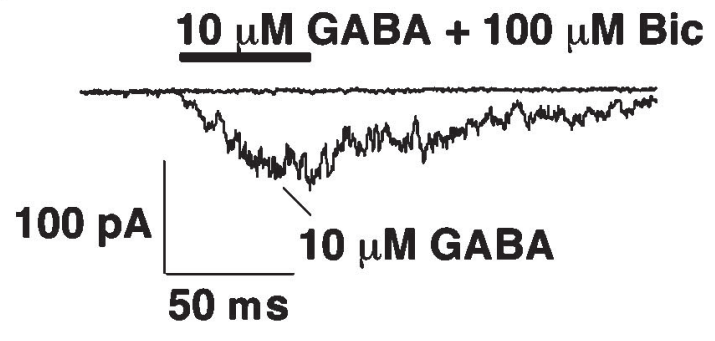

1 mM GABA + $50 \mu M$ Bic

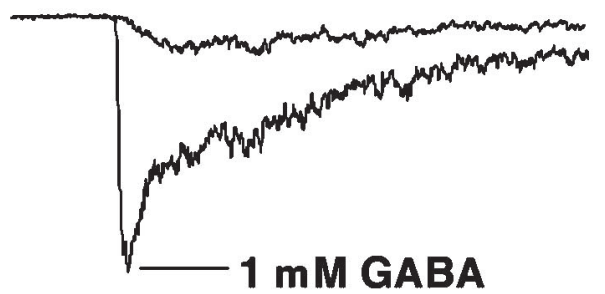

Figure 6. GABA-activated currents in GnRH neurons. A, Fluorescence (left) and IR-DIC (right) images of a nucleated patch of a GFP-expressing GnRH neuron from the DBB of a P47 male GnRH-GFP mouse. B, GABA-evoked currents in a nucleated patch of a GFP-expressing GnRH neuron in the POA of a 6-month-old female GnRH-GFP mouse. GABA $(1 \mathrm{~mm})$ was applied every $5 \mathrm{sec}$ for $50 \mathrm{msec}$ at $V_{\mathrm{h}}$ values of $-100,-80,-60,-40,-20$, $0,20,40,60$, and $80 \mathrm{mV}$. In this and subsequent traces, patches were initially held at $-60 \mathrm{mV}$ and then stepped to a new $V_{\mathrm{h}}$ before agonist and/or antagonist application. Stepping to depolarized test potentials resulted in the outward voltage-gated currents seen before the agonist and/or antagonist response. The voltage-gated currents usually decayed to a steady state by the time of agonist and/or antagonist application. Capacitive currents at the beginning and end of the test pulse are also shown. Scales for these traces and the bottom traces of $D$ are the same. $C$, Current-voltage relationship of the peak responses in $B . D$, Partial inhibition by bicuculline (Bic) of the response to $1 \mathrm{~mm}$ GABA (bottom traces) and full inhibition by bicuculline of the response to $10 \mu \mathrm{M}$ GABA (top traces) at $V_{\mathrm{h}}$ of $-100 \mathrm{mV}$. The patch whose responses are displayed in the bottom traces was from a GnRH neuron in the DBB of a 2-month-old female GnRH-GFP mouse. The patch whose responses are shown in the top traces was from a GnRH neuron in the DBB of a P17 female GnRH-GFP mouse. Capacitive current traces have been blanked.

or to a level near the baseline, indicating complete receptor desensitization within the first $30 \mathrm{msec}$ of the $50 \mathrm{msec}$ application. As with the GABA responses, the current-voltage relationship for the peak current responses to glutamate was linear, with a reversal potential near $0 \mathrm{mV}$ (Fig. $7 A$ ). The fast, desensitizing glutamate-evoked responses were concentration-dependent, with an $\mathrm{EC}_{50}$ in the $100 \mu \mathrm{M}$ to $1 \mathrm{~mm}$ range (Fig. $7 B$ ).

The fast desensitizing response to glutamate $(1 \mathrm{mM})$ was inhibited $(n=4)$ by the AMPA-kainate antagonist NBQX $(5 \mu \mathrm{M})$ (Fig. $7 C$, top traces) and was mimicked $(n=4)$ by AMPA (100 $\mu \mathrm{M})$ (Fig. $7 C$, middle trace). Kainate $(100 \mu \mathrm{M})$ evoked $(n=4)$ a nondesensitizing response (Fig. $7 C$, bottom trace), indicating activation of AMPA receptors as in other neurons (Patneau and
Mayer, 1991). In 5 of 28 patches, the response to glutamate also included a nondesensitizing, slowly deactivating component (Fig. $7 D$, top left traces), with clearly discernible single-channel events between -100 and $-60 \mathrm{mV}$. These properties and the large single-channel conductance $(\sim 70 \mathrm{pS})$ (Fig. $7 D$, bottom left) suggest the signature of NMDA receptors. Indeed, NMDA (1 mM) evoked single-channel events (Fig. 7D, bottom right trace) in two of four patches sensitive to glutamate. AP-5 at a concentration of $50 \mu \mathrm{M}$ did not inhibit (Fig. 7D, top right traces), whereas AP-5 at $500 \mu \mathrm{M}$ did inhibit (Fig. 7D, bottom right traces) the channel. Hence, the NMDA channel activity might be mediated by NR1/ NR2D receptors, which have low affinity for AP-5 (Buller and Monaghan, 1997). 
A

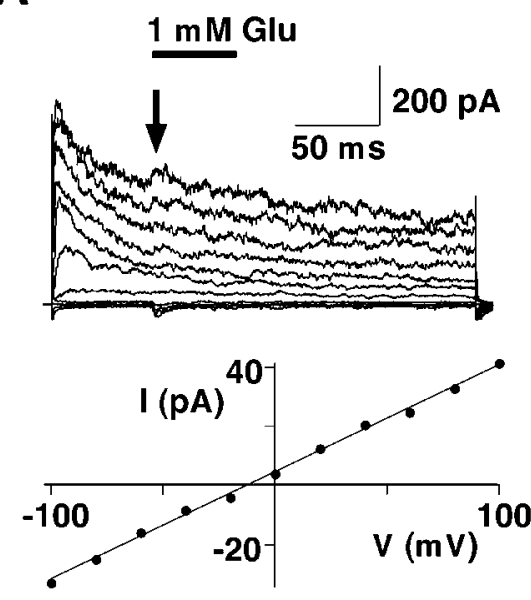

C
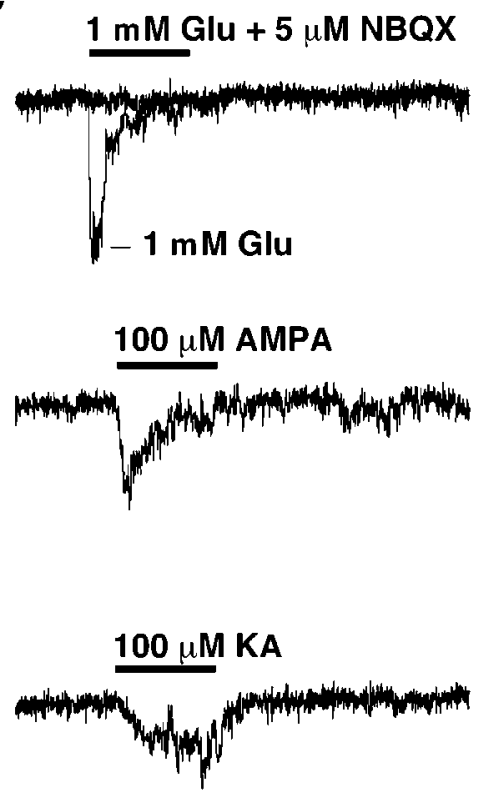

B
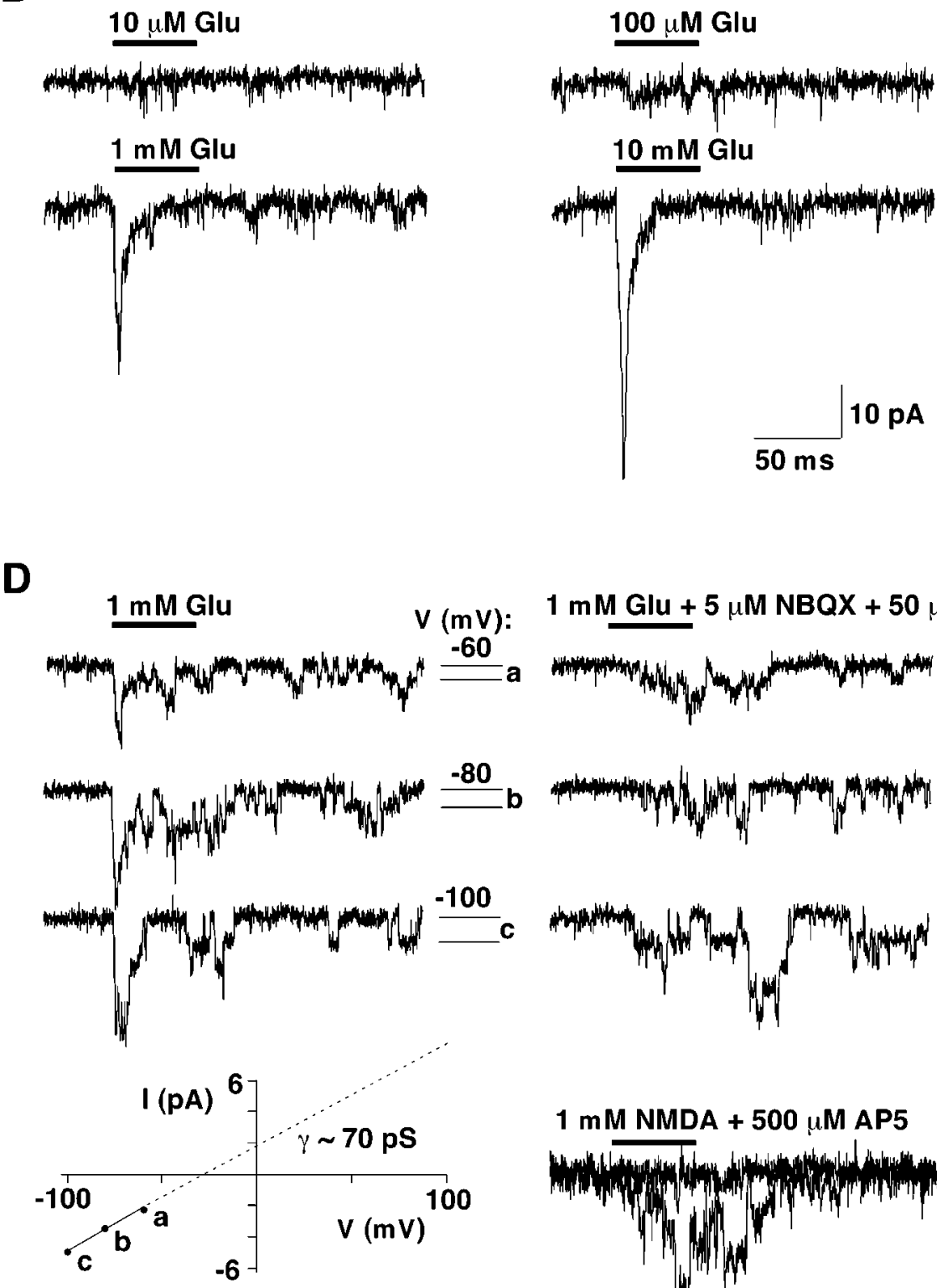

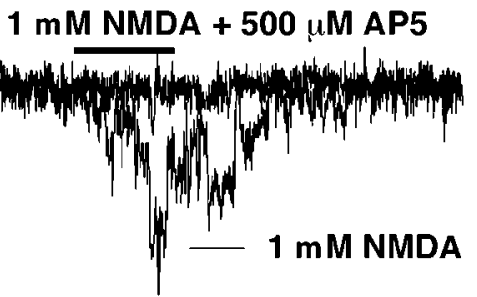

Figure 7. Glutamate-activated currents in GnRH neurons. $A$, Current responses and current-voltage relationship of the peak responses to 1 mM glutamate $(G l u)$. Arrow points to the responses. The patch is the same as that whose responses to 1 mm GABA are shown in Figure $6 B$. $B$, Responses to increasing concentrations of glutamate at $V_{\mathrm{h}}$ of $-100 \mathrm{mV}$. Note the difference in scale compared with that in $A$. The patch was from a GnRH neuron in the DBB of the same mouse whose responses are shown in $A$. Scale is the same in this panel and in $C$ and $D$. $C$, Inhibition of the fast desensitizing component of the glutamate response by NBQX (top traces) and responses to AMPA (middle trace) and kainate (KA; bottom trace), all at $V_{\mathrm{h}}$ of -100 $\mathrm{mV}$. The NBQX-sensitive glutamate responses were from a GnRH neuron in the DBB of a P17 female GnRH-GFP mouse. The AMPA and kainate responses were from a GnRH neuron in the DBB of a 6-month-old female GnRH-GFP mouse. D, Nondesensitizing single-channel responses to glutamate in the absence (top left) and presence (top right) of a cocktail of NBQX and AP-5 at $V_{\mathrm{h}}$ values of $-60,-80$, and $-100 \mathrm{mV}$; current-voltage relationship of the single-channel responses (bottom left); and a response to NMDA at $V_{\mathrm{h}}$ of $-100 \mathrm{mV}$ (bottom right). The slope of the current-voltage relationship of the single-channel events (bottom left), which is equivalent to the single-channel conductance $(\gamma)$, was estimated to be $\sim 70 \mathrm{pS}$. The single-channel responses to glutamate (top left and right) were from a GnRH neuron neighboring the GnRH neuron whose NBQX-sensitive responses are shown in $C$. Response to NMDA and inhibition by AP-5 (bottom right traces) in a patch from a GnRH neuron in the DBB of a 2-month-old male GnRH-GFP mouse.

For comparison, we recorded GABA and glutamate responses from nucleated patches of neighboring nonfluorescent neurons. These patches also exhibited larger responses to GABA (Fig. $8 A$ ) than to glutamate (Fig. $8 B$ ). At $\mathrm{V}_{\mathrm{h}}$ of $-100 \mathrm{mV}$, for example, the peak GABA and glutamate responses in nonfluorescent neurons were $-1569 \pm 402$ and $-270 \pm 51 \mathrm{pA}$, respectively $(n=8)$. Both responses were larger $(p<0.05)$ than those in GnRH neurons and desensitized only partially. Similar to the GnRH neurons, the current-voltage relationships for the GABA and glutamate responses in nonfluorescent neurons were linear, with reversal potentials near $0 \mathrm{mV}$ (Fig. $8 C$ ). The GABA response was bicuculline-sensitive (Fig. $8 D)$. The glutamate $(1 \mathrm{~mm})$ response 
A

\section{1 mM GABA}

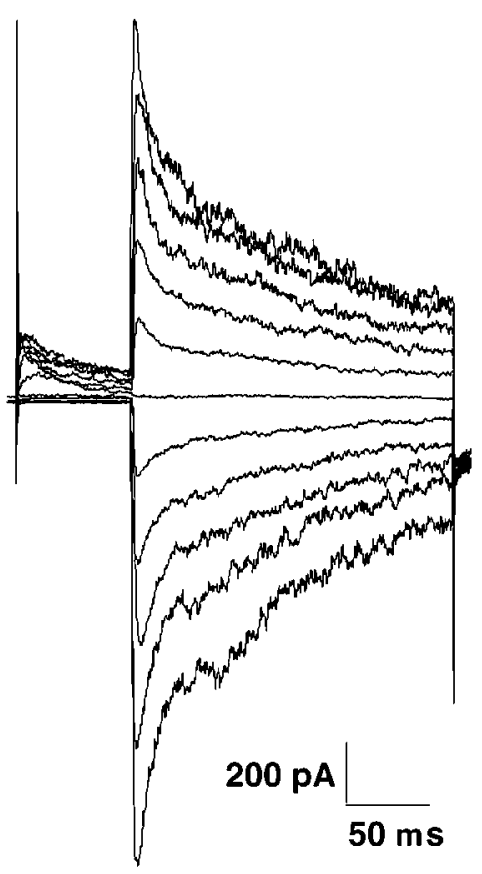

D

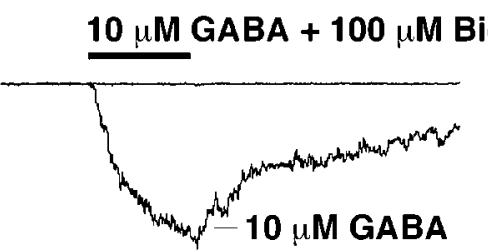

$1 \mathrm{mM}$ GABA + $50 \mu \mathrm{M}$ Bic

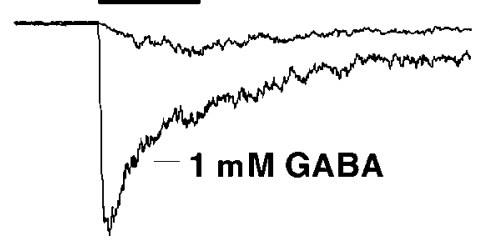

B

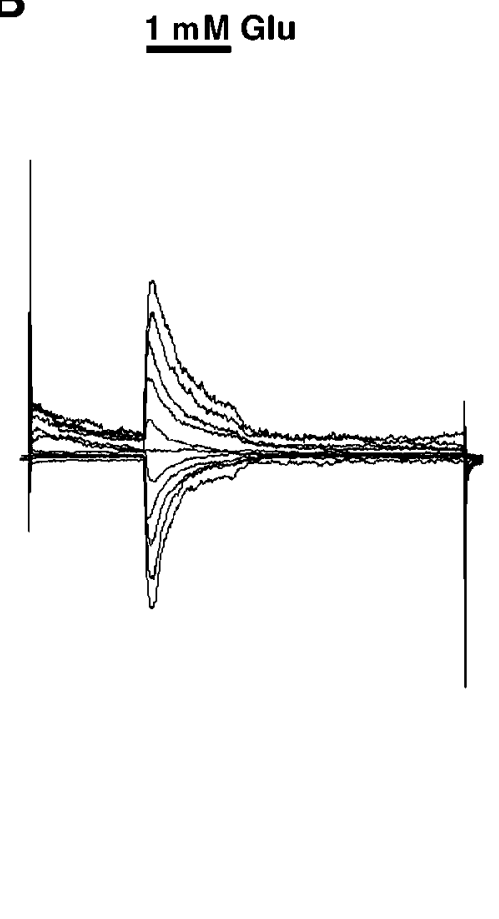

$1 \mathrm{mM}$ Glu

C

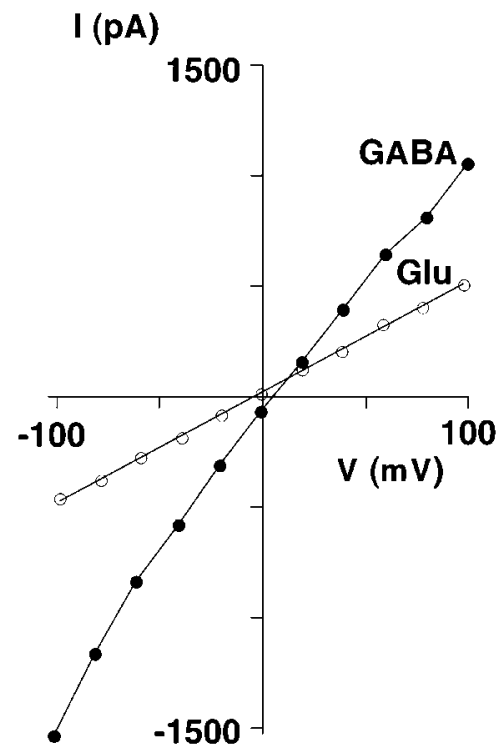

E

$1 \mathrm{mM}$ Glu $+5 \mu \mathrm{M}$ NBQX $+50 \mu \mathrm{M}$ AP5

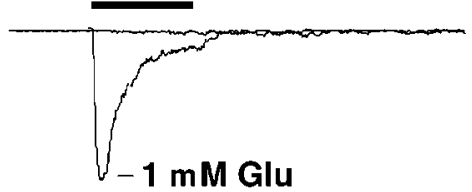

200 pA

$50 \mathrm{~ms}$
F

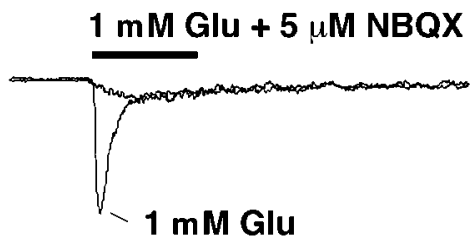

$1 \mathrm{mM}$ Glu $+50 \mu \mathrm{M}$ AP5

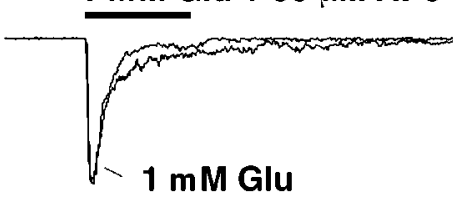

Figure 8. GABA- and glutamate-activated channels in nucleated patches of nonfluorescent, non-GnRH hypothalamic neurons. $A$, GABA (1 mM)evoked currents in a nucleated patch from a nonfluorescent hypothalamic neuron neighboring the GFP-expressing neuron from which the nucleated patch responses in Figure $6 A$ were obtained. Scales are the same in $A$ and $B$. B. Responses to $1 \mathrm{~mm}$ glutamate of the neuron whose GABA responses are shown in $A$. $C$, Current-voltage relationships for the peak responses to GABA and glutamate in $A$ and $B$. $D$, Partial inhibition by $50 \mu \mathrm{M}$ bicuculline of the response to $1 \mathrm{~mm}$ GABA (bottom traces) and complete inhibition by $100 \mu \mathrm{M}$ bicuculline of the response to $10 \mu \mathrm{M}$ GABA (top traces) at $V_{\mathrm{h}}$ of -100 $\mathrm{mV}$. The patches were from neurons neighboring the GFP-expressing GnRH neurons whose bicuculline-sensitive GABA responses are shown in Figure $6 D$. E , Complete inhibition by a cocktail of NBQX and AP-5 of the glutamate response at $V_{\mathrm{h}}$ of $-100 \mathrm{mV}$. The patch was from the same neuron whose responses are illustrated in the bottom traces of $D$. F. Inhibition by NBQX of the fast desensitizing component (top traces) and by AP-5 of the nondesensitizing component (bottom traces) of the glutamate response. The patch was from a nonfluorescent neuron in the POA of the same mouse from which the responses of a GnRH neuron (Fig. 7C, top traces) were obtained.

was blocked completely by a cocktail of NBQX $(5 \mu \mathrm{M})$ and AP-5 $(50 \mu \mathrm{M})$ (Fig. $8 E)$. The desensitizing component of the glutamate response was blocked by $\mathrm{NBQX}(5 \mu \mathrm{M})$ alone (Fig. $8 F$, top traces), and the nondesensitizing component was blocked by AP-5 (50 $\mu \mathrm{M})$ alone (Fig. $8 F$, bottom traces).

\section{DISCUSSION}

We have generated three transgenic mouse lines in which the GFP gene is expressed in a reproducible pattern from the mouse
GnRH promoter (Mason et al., 1986a,b). In all three lines, GFP fluorescence in the brain, as detected by microscope or CCD camera-based imaging, is limited to GnRH neuronal somata in the olfactory bulb, ganglion terminale, medial and lateral septal nuclei, DBB, POA, retrochiasmatic area, supraoptic nucleus retrochiasmatic, lateral hypothalamic area, and arcuate nucleus, as well as in their processes in these areas and in the OVLT and median eminence. The number and spatial distribution of GFPexpressing GnRH neurons matches that of GnRH neuronal pop- 
ulations described previously (Wray and Hoffman, 1986; Wu et al., 1997), whose pulsatile secretion of GnRH is critical for mammalian reproduction. We cannot exclude that more sensitive fluorescence detection might reveal GFP expression in additional cells in the brain, either reflecting ectopic transgene expression or tracing weak GnRH gene activity in the absence of documented GnRH immunoreactivity. It remains to be seen whether in GnRH-GFP mice GFP is also expressed in other tissues in which GnRH has been found, such as pituitary, testis, prostate, ovary, placenta, mammary gland, and lymphoid organs (Dong et al., 1993; Jacobson et al., 1998).

Combined fluorescence and IR-DIC imaging in brain slices of GnRH-GFP mice permitted recordings from identified live GnRH neurons. Our measurements revealed that these neurons are quiescent or spike at low frequencies. The shape of the spontaneous action potentials in GFP-expressing GnRH neurons, which is similar to that of embryonic GnRH neurons (Kusano et al., 1995), appears to be characteristic of GnRH neurons. Perhaps each type of hypothalamic neuron exhibits a distinctive action potential shape attributable to its expression of voltage and/or calcium-dependent potassium channels, which shape the amplitude and duration of the action potential afterhyperpolarization (Hille, 1992). Other hypothalamic neurons also exhibit distinctive action potentials. For example, warm-sensitive neurons in the POA display action potentials very similar in shape to those of the non-GFP/non-GnRH hypothalamic neurons in Figure 4C (top left panel), and these are different from those of cold-sensitive neurons (Curras et al., 1991) and GnRH neurons (Fig. 4B). Three types of action potentials are observed in the paraventricular nucleus of the hypothalamus, which correspond to magnocellular neurons, parvocellular neurons, and interneurons (Tasker and Dudek, 1991), and which are also distinct from those of GnRH neurons.

Whereas the shape of the action potential afterhyperpolarization appears to be characteristic of GnRH neurons, the parameters listed in Table 1 are not. Various aspects of the spontaneous action potentials of GFP-expressing GnRH neurons (threshold, amplitude, duration at half-amplitude, etc.), as well as their passive electrical properties and evoked electrical activity, were similar to those of non-GFP-expressing hypothalamic neurons (our observations), to adult GnRH neurons (Lagrange et al., 1995; M. J. Kelly, personal communication), which could only be identified post hoc, to embryonic GnRH neurons in explant culture (Kusano et al., 1995), and to immortalized GnRH neurons in culture (Hales et al., 1994). However, we have so far not observed oscillatory bursts of action potentials (Bosma, 1993) or action potentials with prolonged periods of depolarization (Hales et al., 1994) as have been reported for immortalized GnRH neurons.

The voltage-gated currents in GFP-expressing GnRH neurons described here resembled those in immortalized (Bosma et al., 1993; Hales et al., 1994; Spergel et al., 1996) and embryonic (Kusano et al., 1995) GnRH neurons. GnRH neurons displayed sodium current, a transient A-type and/or calcium-activated outward potassium current, and a delayed rectifier potassium current as in embryonic (Kusano et al., 1995) and immortalized (Bosma, 1993; Spergel et al., 1996) GnRH neurons. With the extracellular and intracellular solutions used, inward L- and T-type calcium currents, which are present in embryonic (Kusano et al., 1995) and immortalized (Bosma, 1993; Hales et al., 1994) GnRH neurons, would have been masked by the outward potassium currents.

Similarly, the bicuculline-sensitive GABA-evoked currents in
GFP-expressing GnRH neuronal somata were like those reported for immortalized (Hales et al., 1994) and embryonic (Kusano et al., 1995) GnRH neurons and indicate that postembryonic GnRH neurons also express GABA-A receptors. Indeed, the presence of functional somatic GABA-A receptors in GnRH neurons is consistent with data showing that GABAergic neurons synapse on GnRH neurons in the POA (Leranth et al., 1985a), that at least a fraction of GnRH neurons express GABA-A receptor subunits (Jung et al., 1998), and that GABA can increase or decrease GnRH secretion depending on the age of the animal (Feleder et al., 1996). Interestingly, immortalized GnRH neurons have been shown recently to release GABA, suggesting that GABA may influence GnRH secretion in a paracrine manner (Ahnert-Hilger et al., 1998). These reports, together with those illustrating the excitatory actions of GABA in immortalized (Hales et al., 1994) and embryonic (Kusano et al., 1995) GnRH neurons, indicate that GABA can influence GnRH secretion by acting directly on GnRH neurons.

Like GABA, glutamate may play an important role in modulating GnRH secretion. The actions of exogenous glutamate and its various subtype-specific receptor agonists and antagonists suggested that endogenous glutamate increases $\mathrm{GnRH}$ and luteinizing hormone release and that glutamate participates in the induction of puberty, the preovulatory luteinizing hormone surge, and seasonal breeding (for review, see Brann, 1995). However, it was unclear whether these effects were mediated by direct actions of glutamate on GnRH neurons or by indirect actions via connecting neurons. Although membrane potential, calcium, and $\mathrm{GnRH}$ secretory responses to glutamate in immortalized (Mahachoklertwattana et al., 1994; Spergel et al., 1994) and embryonic (Kusano et al., 1995) GnRH neurons indicated the presence of glutamate receptors in these cells, double-label immunocytochemical and in situ hybridization studies of postembryonic GnRH neurons (Abbud and Smith, 1995; Eyigor and Jennes, 1996; Gore et al., 1996) suggested that these neurons express few, if any, glutamate receptors. The glutamate-evoked currents in GnRH neurons presented here provide strong evidence that postembryonic GnRH neurons indeed express functional glutamate receptors.

Our observation of a desensitizing glutamate response, which was inhibited by NBQX, in all of the GnRH neuronal somata we examined, and of a nondesensitizing response in only one-fifth, suggests that the glutamate response in GnRH neuronal somata is mediated primarily by AMPA receptors and to a lesser extent by NMDA receptors. The AMPA receptors of GnRH neuronal somata appear to contain the GluR-B subunit, as indicated by the nonrectifying current-voltage relationship of their desensitizing glutamate response (Burnashev et al., 1992). The nondesensitizing, slowly deactivating response to glutamate with its large single-channel conductance might be that of the NR1/NR2D subtype of NMDA receptor, which deactivates more slowly (Monyer et al., 1994; Wyllie et al., 1998), is less sensitive to AP-5 than the other NR1/NR2 subtypes (Buller and Monaghan, 1997), and is expressed in the DBB (Buller et al., 1994). The paucity of functional NMDA receptor expression that we detected among GnRH neuronal somata is consistent with the finding that only one-fifth of GnRH neurons immunostain for the NMDA receptor subunit NR1 (Gore et al., 1996). Nevertheless, the subunit composition and subcellular (synaptic vs somatic) distribution of the glutamate receptors in GnRH neurons remain to be determined.

The GnRH-GFP transgenic mice will facilitate studies of the cellular basis of pulsatile and neurotransmitter-modulated GnRH 
release. They can be used to investigate synaptic coupling of GnRH neurons to other GnRH neurons (Leranth et al., 1985b) and to non-GnRH neurons, which may be important for pulse generation and its modulation, as well as the manner in which GnRH neuronal physiology varies with brain region, age, sex, reproductive state, and environmental factors.

\section{REFERENCES}

Abbud R, Smith MS (1995) Do GnRH neurons express the gene for the NMDA receptor? Brain Res 690:117-120.

Ahnert-Hilger G, John M, Kistner U, Wiedenmann B, Jarry H (1998) Immortalized gonadotropin-releasing hormone neurons secrete $\gamma$-aminobutyric acid-evidence for an autocrine regulation. Eur J Neurosci 10:1145-1152.

Bosma MM (1993) Ion channel properties and episodic activity in isolated immortalized gonadotropin-releasing hormone neurons. J Membr Biol 136:85-96.

Brann DW (1995) Glutamate: a major excitatory transmitter in neuroendocrine regulation. Neuroendocrinology 61:213-225.

Brusa R, Zimmermann F, Koh D-S, Feldmeyer D, Gass P, Seeburg PH, Sprengel R (1995) Early-onset epilepsy and postnatal lethality associated with an editing-deficient GluR-B allele in mice. Science 270:1677-1680.

Buller AL, Monaghan DT (1997) Pharmacological heterogeneity of NMDA receptors: characterization of NR1a/NR2D heteromers expressed in Xenopus oocytes. Eur J Pharmacol 320:87-94.

Buller AL, Larson HC, Schneider BE, Beaton JA, Morrisett RA, Monaghan DT (1994) The molecular basis of NMDA receptor subtypes: native receptor diversity is predicted by subunit composition. J Neurosci 14:5471-5484.

Burnashev N, Monyer H, Seeburg PH, Sakmann B (1992) Divalent ion permeability of AMPA receptor channels is dominated by the edited form of a single subunit. Neuron 8:189-198.

Chalfie M, Tu Y, Euskirchen G, Ward WW, Prasher DC (1994) Green fluorescent protein as a marker for gene expression. Science 263:802-805.

Curras MC, Kelso SR, Boulant JA (1991) Intracellular analysis of inherent and synaptic activity in hypothalamic thermosensitive neurones in the rat. J Physiol (Lond) 440:257-271.

Dodt H-U, Ziegelgänsberger W (1990) Visualizing unstained neurons in living brain slices by infrared DIC-videomicroscopy. Brain Res 537:333-336.

Dong KW, Yu KL, Roberts JL (1993) Identification of a major upstream transcription start site for the human progonadotropin-releasing hormone gene used in reproductive tissues and cell lines. Mol Endocrinol 7:1654-1666.

Ebling FJP, Alexander IHM, Urbanski HF, Hastings MH (1995) Effects of N-methyl-D-aspartate (NMDA) on seasonal cycles of reproduction, body weight and pelage colour in the male Siberian hamster. J Neuroendocrinol 7:555-566.

Eyigor O, Jennes L (1996) Identification of glutamate receptor subtype mRNAs in gonadotropin-releasing hormone neurons in rat brain. Endocrine 4:133-139.

Feleder C, Jarry H, Leonhardt S, Wuttke W, Moguilevsky JA (1996) The GABAergic control of gonadotropin-releasing hormone secretion in male rats during sexual maturation involves effects on hypothalamic excitatory and inhibitory amino acid systems. Neuroendocrinology 64:305-312.

Gore AC, Wu TJ, Rosenberg JJ, Roberts JL (1996) Gonadotropinreleasing hormone and NMDA receptor gene expression and colocalization change during puberty in female rats. J Neurosci 16:5281-5289.

Hales TG, Sanderson MJ, Charles AC (1994) GABA has excitatory actions on GnRH-secreting immortalized hypothalamic (GT1-7) neurons. Neuroendocrinology 59:297-308.

Heim R, Tsien RY (1996) Engineering green fluorescent protein for improved brightness, longer wavelengths, and fluorescence energy transfer. Curr Biol 6:178-182.

Hille B (1992) Ionic channels of excitable membranes. Sunderland, MA: Sinauer.

Jacobson JD, Crofford LJ, Sun L, Wilder RL (1998) Cyclical expression of GnRH and GnRH receptor mRNA in lymphoid organs. Neuroendocrinology 67:117-125.
Jonas P (1995) Fast application of agonists to isolated membrane patches. In: Single-channel recording (Sakmann B, Neher E, eds), pp 231-243. New York: Plenum.

Jung H, Shannon EM, Fritschy J-M, Ojeda SR (1998) Several GABA receptor subunits are expressed in LHRH neurons of juvenile female rats. Brain Res 780:218-229.

Kusano K, Fueshko S, Gainer H, Wray S (1995) Electrical and synaptic properties of embryonic luteinizing hormone-releasing hormone neurons in explant cultures. Proc Natl Acad Sci USA 92:3918-3922.

Lagrange AH, Ronnekleiv OK, Kelly MJ (1995) Estradiol-17 $\beta$ and $\mu$-opioid peptides rapidly hyperpolarize GnRH neurons: a cellular mechanism of negative feedback? Endocrinology 136:2341-2344.

Leranth C, MacLusky NJ, Sakamoto H, Shanabrough M, Naftolin F (1985a) Glutamic acid decarboxylase-containing axons synapse on LHRH neurons in the rat medial preoptic area. Neuroendocrinology 40:535-589.

Leranth CS, Serguram LMG, Palkovits M, MacLusky NJ, Shanabrough M, Naftolin F (1985b) The LHRH containing neuronal network in the preoptic area of the rat: demonstration of LHRH containing nerve terminals in synaptic contact with LHRH neurons. Brain Res 345:332-336.

Levine JE, Ramirez VD (1982) Luteinizing hormone-releasing hormone release during the rat estrous cycle and after ovariectomy, as estimated with push-pull cannulae. Endocrinology 111:1439-1448.

Lopez FJ, Merchenthaler IJ, Moretto M, Negro-Vilar A (1998) Modulating mechanisms of neuroendocrine cell activity - the LHRH pulse generator. Cell Mol Neurobiol 18:125-146.

Mahachoklertwattana P, Sanchez J, Kaplan SL, Grumbach MM (1994) $\mathrm{N}$-methyl-D-aspartate receptors mediate the release of gonadotropinreleasing hormone $(\mathrm{GnRH})$ by NMDA in a hypothalamic GnRH neuronal cell line (GT1-1). Endocrinology 134:1023-1030.

Mason AJ, Hayflick JS, Zoeller T, Young WS, Phillips HS, Nikolics K, Seeburg PH (1986a) A deletion truncating the gonadotropin-releasing hormone gene is responsible for hypogonadism in the hpg mouse. Science 234:1366-1371.

Mason AJ, Pitts SL, Nikolics K, Szonyi E, Wilcox JN, Seeburg PH, Stewart TA (1986b) The hypogonadal mouse: reproductive functions restored by gene therapy. Science 234:1372-1378.

Mellon PL, Windle JJ, Goldsmith PC, Padula CA, Roberts JL, Weiner RI (1990) Immortalization of hypothalamic GnRH neurons by genetically targeted tumorigenesis. Neuron 5:1-10.

Monyer H, Burnashev N, Laurie DJ, Sakmann B, Seeburg PH (1994) Developmental and regional expression in the rat brain and functional properties of four NMDA receptors. Neuron 12:529-540.

Patneau DK, Mayer ML (1991) Kinetic analysis of interactions between kainate and AMPA: evidence for activation of a single receptor in mouse hippocampal neurons. Neuron 6:785-798.

Sakmann B, Stuart G (1995) Patch-pipette recordings from the soma, dendrites, and axon of neurons in brain slices. In: Single-channel recording (Sakmann B, Neher E, eds), pp 199-211. New York: Plenum.

Sather W, Dieudonné S, MacDonald JF, Ascher P (1992) Activation and desensitization of N-methyl-D-aspartate receptors in nucleated outsideout patches from mouse neurones. J Physiol (Lond) 450:643-672.

Schwanzel-Fukuda M, Pfaff DW (1989) Origin of luteinizing hormonereleasing hormone neurons. Nature 338:161-164.

Silverman A-J, Witkin JW, Millar RP (1990) Light and electron microscopic immunocytochemical analysis of antibodies directed against $\mathrm{GnRH}$ and its precursor in hypothalamic neurons. J Histochem Cytochem 38:803-813.

Spergel DJ, Krsmanovic LZ, Stojilkovic SS, Catt KJ (1994) Glutamate modulates $\left[\mathrm{Ca}^{2+}\right]_{\mathrm{i}}$ and gonadotropin-releasing hormone secretion in immortalized hypothalamic GT1-7 neurons. Neuroendocrinology 59:309-317.

Spergel DJ, Catt KJ, Rojas E (1996) Immortalized GnRH neurons express large-conductance calcium-activated potassium channels. Neuroendocrinology 63:101-111.

Suchanek B, Seeburg PH, Sprengel R (1997) Tissue specific control regions of the N-methyl-D-aspartate receptor subunit NR2C promoter. Biol Chem 378:929-934.

Tasker JG, Dudek FE (1991) Electrophysiological properties of neurones in the region of the paraventricular nucleus in slices of rat hypothalamus. J Physiol (Lond) 434:271-293. 
Whyte DB, Lawson MA, Belsham DD, Eraly SA, Bond CT, Adelman JP, Mellon PL (1995) A neuron-specific enhancer targets expression of the gonadotropin-releasing hormone gene to hypothalamic neurosecretory neurons. Mol Endocrinol 9:467-477.

Winer BJ (1971) Statistical principles in experimental design. New York: McGraw-Hill.

Wolfe AM, Wray S, Westphal H, Radovick S (1996) Cell-specific expression of the human gonadotropin-releasing hormone gene in transgenic animals. J Biol Chem 271:20018-20023.

Wray S, Hoffman G (1986) A developmental study of the quantitative distribution of LHRH neurons within the central nervous system of postnatal male and female rats. J Comp Neurol 252:522-531.
Wray S, Grant P, Gainer H (1989) Evidence that cells expressing luteinizing-releasing hormone mRNA are derived from progenitor cells in the olfactory placode. Proc Natl Acad Sci USA 86:8132-8136.

Wu TJ, Gibson MJ, Rogers MC, Silverman AJ (1997) New observations on the development of the gonadotropin-releasing hormone system in the mouse. J Neurobiol 33:938-998.

Wyllie DJA, Béhé P, Colquhoun D (1998) Single-channel activations and concentration jumps: comparison of recombinant NR1a/NR2A and NR1a/NR2D NMDA receptors. J Physiol (Lond) 510:1-18.

Zolotukhin S, Potter M, Hauswirth WW, Guy J, Muzyczka N (1996) A "humanized" green fluorescent protein cDNA adapted for high-level expression in mammalian cells. J Virol 70:4646-4654. 